\title{
Biological monitoring of freshwater ecosystem health in Ethiopia: A review of current efforts, challenges, and future developments
}

\author{
Workiye Worie Assefa ${ }^{1, *}$, Getachew Beneberu ${ }^{1}$, Baye Sitotaw ${ }^{2}$, and Ayalew Wondie ${ }^{3}$ \\ ${ }^{1,2}$ Department of Biology, College of Science and ${ }^{1}$ Blue Nile Water Institute, Bahir Dar \\ University, Bahir Dar, Ethiopia \\ ${ }^{3}$ School of Fisheries and Wildlife, College of Agriculture and Environmental Sciences, \\ Bahir Dar University, Bahir Dar, Ethiopia
}

\begin{abstract}
Aquatic resources are increasingly stressed primarily due to anthropogenic activities in Ethiopia. These anthropogenic stresses altered ecological integrities and compromised ecosystem services that could otherwise support the livelihoods of millions of people. Evidence-based management of the degradation of aquatic ecosystems requires quantifying ecologically significant changes and discriminating among impact levels and types. Apart from physico-chemistry, monitoring of aquatic ecosystems using biological organisms is progressing well in recent times both in the tropics and temperate regions. The majority of studies so far focused on macroinvertebrates and to a lesser extent on diatoms. Though the method is given less attention, individual initiatives have been increasing over time especially in developing countries, including Ethiopia. This paper reviews current efforts undertaken and major challenges facing the use of bioindicators in aquatic ecosystems as biological monitoring tools. The possible application of biomonitoring and its importance for Ethiopian aquatic ecosystems is also discussed and future improvements suggested.
\end{abstract}

Keywords: Anthropogenic pressures, Bioassessment, Ecological Integrity, Indicators, Pollution.

DOI: https://dx.doi.org/10.4314/ejst.v13i3.5

\section{INTRODUCTION}

\section{Anthropogenic impacts on Ethiopian freshwater ecosystems}

Ethiopia is endowed with many lakes and rivers supporting diverse freshwater ecosystems covering an estimated surface area of $18,587 \mathrm{~km}^{2}$ (EEPA, 2010). The

\footnotetext{
* Corresponding author: workiye2008@gmail.com

(C) This is an Open Access article distributed under the terms of the Creative Commons Attribution License (http://creativecommons.org/licenses/CC BY4.0)
} 
majority of lakes are concentrated in the Rift Valley basin, which is productive as well as rich in biodiversity (Tudorancea and Taylor, 2002), while others are found elsewhere except in some low and dryland areas. Lakes, rivers, and wetlands support livelihoods by providing numerous ecosystem services (EWNHS, 2018). These services include potable water, sand and soda ash mining, fishing, flood attenuation, waste treatment, home for flora and fauna, irrigation, navigation, electric power generation, and other ecosystem services. Thus, utilizing freshwater ecosystems without compromising its ecological integrity determines future developmental needs and the societal well-being of the country (Nel et al., 2011).

The unwise use of water resources for various purposes has impacted aquatic ecosystems (Abebe Getahun and Stiassny, 1998; Zinabu G/Mariam et al., 2002). Water diversion from Lake Tana for irrigation and floriculture, for instance, damages the ecological integrity of the lake and its inhabitants, particularly the indigenous and endemic fish species (Ayalew Wondie, 2010; Wassie Anteneh et al., 2010). Lake Tana is designated as a Biosphere Reserve by UNESCO, which means that urgent action and proper management is needed. We lost Lake Haramaya decades ago, and Lake Abijata, which used to support a large number of Great White Pelicans and Lesser Flamingo, which left bird species on the verge of collapse due to soda ash extraction and other activities (Zinabu G/Mariam et al., 2002).

Wetlands in Ethiopia also face similar problems due to anthropogenic activities such as agricultural and domestic wastes that affect biodiversity and ecological services (Ayalew Wondie, 2010, 2018). Irrigation and hydropower development projects in the country rarely consider the hydrology and hydrogeology of water resources (Tenalem Ayenew, 2007; Tenalem Ayenew and Dagnachew Legesse, 2007). Freshwater ecosystems in Ethiopia, in general, are threatened by human activities, but by far the most severe damage occurs due to poor agricultural practices and industries (Seleshi Bekele et al., 2012). Agricultural practices damage the quality and quantity of nearby water bodies. Farmers utilize fertilizers and pesticides, the result of which is ultimately eutrophication and toxic Cyanobacteria (Tadesse Fetahi, 2019). Soil erosion fills aquatic ecosystems with sediment in many river basins of Ethiopia (Seleshi Bekele et al., 2012). It was estimated that 21 to $32 \mathrm{tha}^{-1} \mathrm{yr}^{-1}$ of sediment is transported from the upper watershed and retained in the flood plains and Lake Tana (Fasikaw Atanaw et al., 2018). The main cause of this sedimentation is deforestation (Kloos and Worku Legesse, 2010), uncontrolled grazing, poor farming practices, and unsustainable land use land cover changes. Urban development and the construction of roads also add sediment to wetlands, lakes, and rivers (Kloos and 
Worku Legesse, 2010; Graichen, 2011). According to Zinabu G/Mariam (1998), urbanization and human settlement near lakes in Ethiopia are the major factors affecting water quality and content. Many beautiful wetlands rich in papyrus reeds are drained for office and hotel construction in Bahir Dar (Pers. obs.). Water bodies near cities have shown signs of severe pollution because of recently emerging industries. Industrial and municipal wastes are directly released into wetlands, lakes, and rivers without prior treatment (Getachew Beneberu and Seyoum Mengistou, 2014). For instance, the Addis Ababa Environmental Protection Authority (EEPA) reported that more than $90 \%$ of the industries in Addis Ababa are operating without any wastewater treatment systems (EEPA, 2005). Zinabu G/Mariam and Elias Dadebo (1989) reported that the Rift Valley lakes and their feeder streams receive domestic and industrial organic wastes, and toxic chemicals from textile factories, distillers, and plywood factories, and agrochemicals. These contaminants harm the environment in many ways: species get replaced, toxins bioaccumulate and biomagnify toxic metals and pesticides in the food chain (Zinabu G/Mariam et al., 2002).

Therefore, the impact of these human activities on aquatic ecosystems need to be monitored using cost-effective monitoring tools. So far in Ethiopia, these anthropogenic impacts on freshwater ecosystems have been assessed mainly using the traditional approach of physico-chemical variables. However, these analyses cannot be done on-site and need expensive reagents and instruments that are not easily available in developing countries. Moreover, this approach does not allow establishing cause and effect relationships between inhabiting organisms and causative agents (Wolska et al., 2007). In East Africa, including Ethiopia, the use of biological organisms for the assessment and monitoring of freshwater ecosystem conditions is uncommon. In recent times, however, the management and conservation of freshwater resources in Africa have shifted to an improved understanding of species-environment relationships and development of new methodologies and frameworks to assess and monitor the health of aquatic ecosystems (Chutter, 1998; Kleynhans, 1999; Dickens and Graham, 2002). Biological monitoring is the use of biological responses to evaluate changes in the environment, mostly focusing on human impacts (Cairns et al., 1982). Biological monitoring provides a direct measure of ecological integrity by integrating various stressors. Biological indicators reinforce physico-chemical indicators and facilitate far better assessment and management of freshwater ecosystems (Bartram and Balance, 1996; Lobo et al., 2004). According to previous studies, biological indices derived from biological organisms are better indicators than the traditional method, as they indicate all kinds of anthropogenic disturbances and their cumulative impacts on aquatic ecosystems (Muralidharan et al., 2010). Biological monitoring programs are 
increasingly recognized around the world as they are fast, integrated, and costeffective for assessing the consequences of environmental stressors on aquatic ecosystems. This paper is a review of current efforts done so far concerning the use of bioindicators and major challenges hindering their application in Ethiopia.

\section{The concept of biomonitoring/bioassessment}

Biological monitoring is one of the available instruments used to assess the status and degree of impairment of aquatic ecosystems (Birk et al., 2012). Biotic component measurements in aquatic ecosystems provide information about environmental stress, which otherwise might be missed by periodic or continuous monitoring of physical and chemical factors (USEPA, 1987). Surveying and assessing the status of these aquatic communities and the quality of their habitats are the major principal tools for biomonitoring. Although the use of biomonitoring for pollution assessment goes back to 1909 (Kolkwitz and Marsson, 1909), its use for freshwater resource management in the tropics is not that progressive. The effect of environmental stress can be reflected by the organism's attributes such as presence/absence, abundance, or behavioral changes (Bonada et al., 2006). The biota that frequently appeared in the most bioassessment programs includes macroinvertebrates, fish, and algae (Resh, 2008). The use of biota for biomonitoring has several advantages over the traditional monitoring approaches. The advantages include having diverse ecological requirements, cost, life cycles/strategies are different, and are unevenly distributed over space and time and thus can integrate the effects of pressure over space and time (Barbour et al., 1999; De Pauw et al., 2006). Assessing pollutants exhibiting temporal variation using traditional methods are very expensive, and the results may not be biologically dependable (Bonada et al., 2006, Friberg et al., 2011). Thus, biomonitoring is a vital tool for assessing the extent of anthropogenic impacts on freshwater ecosystems. However, the underlying cause of biotic index score deviation is unclear and the impacts cannot be attributed to a single pressure (Clews and Ormerod, 2009), which are considered as a weakness of biomonitoring tools. The applicability of these biological monitoring methods for developing countries, unless harmonized, is questionable (Everaert et al., 2014). That is why many countries have developed their own biological indices according to local conditions.

\section{METHODOLOGY}

Published articles on biological monitoring of Ethiopian freshwater ecosystem health were searched using academic databases and search engines (such as 
Elsevier-Scopus, Web of Science, Science Direct, Google Scholar, and Mendeley) from 1988 to 2019. Besides, the grey literature of M.Sc. and Ph.D. thesis works were assessed from research institutions and universities. The search terms and phrases were combinations of keywords such as aquatic plants, algae, benthic macroinvertebrates, macrophytes, diatoms, fish, water quality, freshwater ecosystems, bioindicators, bioassessment, biomonitoring, organic pollution, physicochemical assessment, rivers/streams, wetlands, lake, and water resources management.

The following criteria were used for selecting articles: 1) studies conducted in Ethiopian aquatic ecosystems; 2) studies involving biological organisms to evaluate the health of aquatic environments; and 3) published and unpublished articles written in English. Furthermore, we have included some papers that, in the opinion of the authors, include information or theoretical concepts that are relevant to our narrative review work. The use of biological organisms for aquatic bioassessment in Ethiopia started in recent times, and thus all the available papers were considered in the review process. The number of research papers containing biological monitoring of freshwater environments in Ethiopia increased over the years, providing more efforts on the river and stream ecosystem (Figure 1a). Indeed, more than $95 \%$ of the studies were published from 2009 onwards. The majority of these studies have been published in peerreviewed international journals and are available to international audiences (Figure 1). Only 2 articles were published in local journals (Figure 1c). Most of the studies have been conducted in localities where universities have opened Fisheries and Aquatic Science programs.

After selecting and assessing contents, the results and conclusions of 35 relevant papers were evaluated against the specific methods they applied, and compared among study results with similar ecological settings.

\section{BIOMONITORING PRACTICES IN ETHIOPIA}

\section{Biomonitoring approaches using macroinvertebrates}

Macroinvertebrates are a major constituent of freshwater biodiversity, often used as indicator organisms for assessing water quality. 
Many countries have their own protocols on how to use macroinvertebrates to monitor the ecological status of river ecosystems. Bioassessments in the USA and Europe are a mandatory tool for water resources management and are thus supported by strong legislation of the Clean Water Act and Water Framework Directive, respectively (Birk et al., 2012; USEPA, 2013). In Africa, it's not applied satisfactorily except in South Africa, where a scoring system is developed (SASS) using local freshwater macroinvertebrates (Dickens and Graham, 2002).

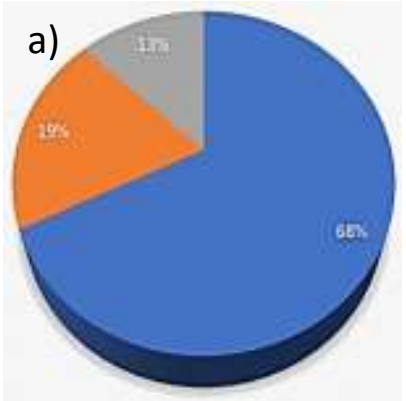

a River/Stroam EWotiand 1 Lie Lie
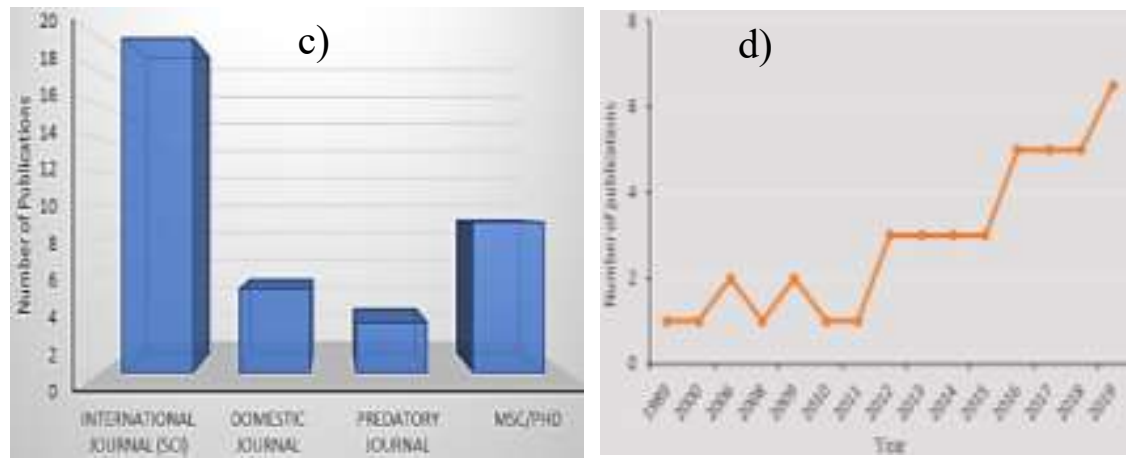

Figure 1. The overview of biological monitoring studies conducted in Ethiopian Freshwater Ecosystems; (a) Distribution of papers among aquatic ecosystem types; (b) distribution of published papers and reports based on indicator organisms; (c) distribution of published papers based on web search engines and academic databases; (d) publication trend over time.

South Africa's method has been modified and widely used in many other African countries such as Namibia (Palmer and Taylor, 2004), Zambia (Lowe et al., 
2013), Ethiopia (Aschalew Lakew and Moog, 2015a) and Tanzania (Kaaya et al., 2015). In Ethiopia, although the importance of macroinvertebrates as bioindicators was recognized in the 1980s (Harrison and Hynes, 1988; Tesfaye Berhe et al., 1989), interest for use in bioassessment has increased in recent times (Figure 1d) (Baye Sitotaw, 2006; Abebe Beyene et al., 2009; Solomon Akalu et al., 2011; Getachew Beneberu et al., 2014; Aschalew Lakew and Moog, 2015a, b). However, the efforts are fragmentary and regionally restricted and there was no effort to develop a unified national bioassessment protocol. This is mainly because aquatic invertebrate research is neglected field in the country (Seyoum Mengistou, 2006). It is a marginalized sector and no institution specialized in aquatic invertebrate research. Some of the recent advances in research trying to develop biotic indices and multimetric indices based on benthic macroinvertebrate communities and other organisms are basically individual interests from some universities and research institutes (Seyoum Mengistou, 2006). These were used to assess water quality and the ecological status of freshwater ecosystems, mainly running waters. Because of lack of standardized protocols, the results are not reliable and cannot be used for comparison purposes with confidence. Among the bioassessment methods, single metric and multimetric approaches have been practiced in Ethiopia to detect ecological changes. Based on macroinvertebrates, the practices of these two approaches are discussed in the following sections.

\section{Single metric}

Single metric is commonly used to monitor the integrity of aquatic ecosystems based on a single biological attribute. Qualitative sampling and family level identification are sufficient without taking into account abundances per taxon (De Pauw et al, 2006). This single metric biotic approach has been widely used around the world and has been successfully adopted for monitoring rivers in Ethiopia as well. For instance, the study of Harrison and Hynes (1988) in Ethiopian mountain streams showed that anthropogenic pressures were the major threatening factors contributing to the eradication of numerous groups of invertebrates in highland streams. Some taxa (e.g. Gerridae and Veliidae) have become rare in the studied streams and rivers due to the intensive use of detergents for washing purposes (Harrison and Hynes, 1988). The order Plecopteran (Perlidae) has almost disappeared from Ethiopian water bodies as it requires well-oxygenated water with a rocky bottom substrate (Getachew Beneberu, 2013). Macroinvertebrate assemblages and composition with physicochemical parameters were also used to assess the ecological status of Ethiopian rivers (Tesfaye Berhe, 1988; Worku Legesse, 2000). Along the Akaki river, for instance, visible changes in macroinvertebrate species composition and density, as well as physical and chemical changes were recorded, and the result was that 
the river was found seriously degraded due to anthropogenic disturbance (Tesfaye Berhe, 1988). Ayenew Gezie et al. (2017), on the other hand, used five metrics of macroinvertebrates in the wetlands of Lake Tana region, which helped successfully identify the gradients of human disturbances. With increased human disturbance, the richness of Ephemeroptera and Odonata (EO), Biological Monitoring Working Party (BMWP) score, family richness, and Shannon diversity index responded negatively, while the Family Biotic Index (FBI) score was increased. Single metrics were also used (Solomon Akalu et al., 2011; Solomon Akalu, 2017) to assess the impacts of human activities on the Greater and Little Akaki rivers. Eleven metrics representing richness, composition, and tolerance/intolerance measures were included in their study. Macroinvertebrate community structures in upstream and downstream were different: the upstream had higher taxa while the middle and downstream sites were dominated by fewer tolerant taxa. The observed change was attributed to nutrient enrichment and oxygen depletion due to the release of untreated industrial and domestic wastes from the city. Community changes along downstream direction were due to the natural phenomenon as explained by the river continuum concept (Vannote et al., 1980). However, this may not be the case all the time as changes in community structure along the Greater Akaki river could not be explained in terms of nature (Solomon Akalu et al., 2011). The Average Score Per Taxon (ASPT) index was employed with success in some streams of Ethiopia (e.g. Aschalew Lakew and Moog, 2015a; Sololom Akalu, 2017). Although sampling sites (3 stations) were considered to be very small, Habiba Gashaw and Seyoum Mengistou (2012) reported that Lake Hora showed symptoms of severe organic pollution and very poor water quality based on Hilsenhoff Family Biotic Index (H-FBI). The high H-FBI value for Lake Hora was because of the abundance of pollution tolerant taxa such as Chironomids with higher tolerance values. Stressor specific problems (siltation, agricultural activities, and paper mill wastes) were identified in the central highland streams of Ethiopia (Aschalew Lakew and Moog, 2015a). Accordingly, five metrics were found to be very helpful in distinguishing the origin of the stressor impacting stream sites. The metrics included taxa richness, \% EPT, \% Oligochaeta and Chironomidae, \% EPT-BCH (EPT with no Baetidae, Caenidae, and Hydropsychidea, and ASPT. Of these, \% EPT-BCH was found to be more successful in discriminating against the impacts of siltation from agriculture and reference sites (Alemayehu Negassa, 2016). Some other macroinvertebrate-based indices (EPT richness, \% EPT, EPTChironomidae ratio, FBI, ETHbios, \% gathering collectors, and \% scrapers) also showed deterioration in the water quality of the Huluka river at downstream sites. This river received a huge amount of untreated sewage discharges from various sources in Ambo town, including agricultural activities of the watershed (Alemayehu Negassa, 2016). Other similar studies have demonstrated Shannon 
diversity index and richness have been effectively used to identify the degree of anthropogenic disturbance in wetland and stream ecosystems (Argaw Ambelu et al., 2010; Abebe Beyene et al. 2012; Melaku Getachew et al., 2012; Assefa Wosnie and Ayalew Wondie, 2014; Temesgen Alemneh et al. 2017; Abrehet Kahsay et al., 2015; Gurmessa Tesfahun and Agumassie Tessema, 2018; Selamawit Nagassa et al., 2018a, b; Sisay Misganaw, 2018).

The metrics derived from macroinvertebrates in our country largely depended on the family-level resolution. In contrast, Getachew Beneberu et al. (2014) worked on a specific group of Chironomids identified to lower taxonomic levels. Chironomid taxa were able to separate the degree of pollution between moderately polluted and heavily polluted sites (Getachew Beneberu et al., 2014). Moreover, the head capsule deformities among Chironomus species were utilized as an indicator of environmental stress in the Sebeta river (Ethiopia). Moderate level of deformities of the species was associated with a worse ecological status of the river (Getachew Beneberu and Seyoum Mengistou, 2014). A study by Mekedes Hone (2016) at the head of the Blue Nile river impacted by tannery wastes showed a high number of Chironomus species (Mekedes Hone, 2016). This is an indication that the genus is tolerant of inorganic and organic pollutants and thus can indicate water quality degradation (Oliveira et al., 2010). A similar study revealed that stream sites receiving wastes directly from the brewery and textile industries were rich in pollution tolerant Chironomid species, namely, Chironomus alluaudi and Chironomus imicola (Amare Mezegebu et al., 2019), which indicate the incidence of poor ecological status. Moderately polluted sites comprised high numbers of Polypedilum wittei, P. bipustulatem, and Dicrotendipus septemmaculatus. On the other hand, the genus Conchapelopia including Chironomus cliptres were common in reference sites (Amare Mezegebu et al., 2019). Therefore, identifying Chironomids to lower taxa (genera and species) could serve as better indicators of water quality for streams and river ecosystems. However, heavily polluted sites on the Sebeta river were characterized by low number of Chironomus, and especially sites with DO levels $<2 \mathrm{mg} / \mathrm{l}$ were devoid of this genus, indicating that extreme pollution may even challenge the survival of this genus (Getachew Beneberu, 2013).

Indices such as BMWP and H-FBI that are developed for temperate regions have also provided satisfactory results in tropical streams (Resh, 2007). 
Workiye Worie et al.

Table 1. Taxa and sensitivity scores of benthic macroinvertebrates for ETHbios calculations (Aschalew Lakew and Moog, 2015a).

\begin{tabular}{|c|c|c|}
\hline Common name & Taxon & Score \\
\hline Stone flies & Perlidae (Neoperla sp.) & 10 \\
\hline Caddis flies & Lepidostomatidae, Philopotamidae & 10 \\
\hline Beetles & Scirtidae & 10 \\
\hline & Baetidae $>2$ spp., Acanthiop sp., Heptageniidae (Afronurus sp.), & \\
\hline Mayflies & Leptophlebiidae & 9 \\
\hline Caddis flies & Hydropsychidae $>2$ spp. & 9 \\
\hline Mayflies & Tricorythidae & 8 \\
\hline Caddis flies & Leptoceridae, Ecnomidae & 8 \\
\hline Beetles & Psephenidae, Stenelmis sp., Microdinodes sp. & 8 \\
\hline Water mites & Hydracarina & 8 \\
\hline Crabs & Potamidae & 7 \\
\hline $\begin{array}{l}\text { Dragonflies, } \\
\text { damselflies }\end{array}$ & Aeshnidae, Lestidae & 7 \\
\hline Beetles & Elmidae & 7 \\
\hline \multirow[t]{2}{*}{ Crane flies } & Tipulidae & 7 \\
\hline & Pisidium sp. & 7 \\
\hline Mollusca & Limpets & 6 \\
\hline Mayflies & Baetidae with 2 spp., Caenidae & 6 \\
\hline Caddis flies & Hydropsychidae with 2 spp. & 6 \\
\hline Dragonflies & Gomphidae & 6 \\
\hline Water bugs & Naucoridae & 6 \\
\hline Horse flies & Tabanidae & 6 \\
\hline Caddis flies & Hydropsychidae with $1 \mathrm{sp}$. & 5 \\
\hline Dragonflies & Coenagrionidae, Libellulidae & 5 \\
\hline Water striders & Mesoveliidae, Veliidae, Gerridae & 5 \\
\hline Beetles & Hydrophilidae, Dytiscidae, Gyrinidae, Haliplidae & 5 \\
\hline Flies & Ceratopogonidae excl. Bezzia-Gr. & 5 \\
\hline \multirow[t]{2}{*}{ Mayflies } & Baetidae with $1 \mathrm{sp}$. & 4 \\
\hline & Corixidae, Pleidae & 4 \\
\hline Water bugs & Belostomatidae, Notonectidae, Nepidae & 3 \\
\hline Leeches & Hirudinea & 3 \\
\hline Snails & Physidae, Bulimus sp. & 3 \\
\hline Midges & Bezzia-group & 3 \\
\hline \multirow[t]{3}{*}{ and Flies } & Musidae, Chironomidae with predominantly Tanytarsini and & \\
\hline & Tanypodinae & 2 \\
\hline & Psychodidae, Ephydridae, Culicidae, Red Chironomidae, & \\
\hline Worms & Oligochaeta & 1 \\
\hline
\end{tabular}

This is because most benthic macroinvertebrate families are cosmopolitan, which may grant a comparable general tolerance value of each family in different regions or continents. This provides a good opportunity to adopt the biotic 
indices by making minor adjustments based on the occurrence of local fauna in relation to water quality parameters (Thorne and Williams, 1997). A single metric approach based on a single parameter from an indicator group has been used in Ethiopia, mainly for riverine ecosystems. The most widely used metrics include \% EPT (Ephemeroptera, Plecoptera, and Trichoptera), FBI, BMWP, and taxa richness (TR). These metrics are easy to apply and best reflect the ecological water quality (Resh, 2007). The only such metrics developed for Ethiopian water bodies is that of Aschalew Lakew and Moog (2015a), which is a modification of the Biological Monitoring Working Party Principles (BMWP) and the South African Scoring system (SASS) (Table 1). ETHbios categorizes five water quality grades (High, Good, Moderate, Poor, and Bad) for highland streams.

\section{Multimetric}

Karr (1981) introduced the concept of a multimetric index approach for the first time to evaluate anthropogenic pressure on freshwater ecosystems using fish communities as bioindicators. Subsequently, this approach was implemented in macroinvertebrates (Plafkin et al., 1989; Barbour et al., 1992; Kerans and Karr, 1994; Karr and Chu, 2000) and wetland vegetation (Gernes and Helgen, 1999; Nichols et al., 2000; Mack, 2001; Gernes and Helgen, 2002; Ferreira et al., 2005; Miller et al., 2006). Multimetric index (MMI) addresses overall multiple impacts and is composed of individual metrics into a unitless index that can be used to judge the ecological conditions of a site. The MMI combines metrics such as taxa richness, diversity measures, the proportion of sensitive and tolerant species, and trophic structure, which are reflecting various dimensions of the environmental conditions and characteristics of the community (Karr and Chu, 2000). Thus, a multi-metric approach is considered a more dependable monitoring tool than assessment methods based on single metrics (Moog et al., 2018). The typical benefit of MMI is its flexibility, which could be easily adapted to other regions for use according to the local conditions (Gabriels et al., 2010; Nguyen et al., 2014). The development of a multi-metric index follows the procedures and steps shown in Figure 2.

In Ethiopia, few studies have been tried to adopt MMI for bioassessment of aquatic ecosystems. In this regard, Baye Sitotaw (2006) was the pioneer providing a comprehensive set of data describing macroinvertebrate communities in 8 streams located in Awash, Blue Nile, Omo-Ghibe, and BaroAkobo basins to develop the Index of Biological Integrity (B-IBI). Among the 17-candidate metrics, only 14 metrics were included in the final index development (Table 2). The index effectively discriminated sampling sites into different impairment levels: severe, slight, moderate, less, and very little. B-IBI and its metric components had significant relationships with many 
physicochemical and habitat quality parameters. But habitat metrics, organic pollution, and water colour showed a strong correlation with B-IBI. Thus, the discriminating power of the index is commendable, which was able to separate urban and agricultural sites from reference sites irrespective of the different geographical locations of the sites. Urban sites supported a very low number of EPT taxa, indicating that these groups of invertebrates are sensitive to excessive nutrient and organic loading (Baye Sitotaw, 2006).

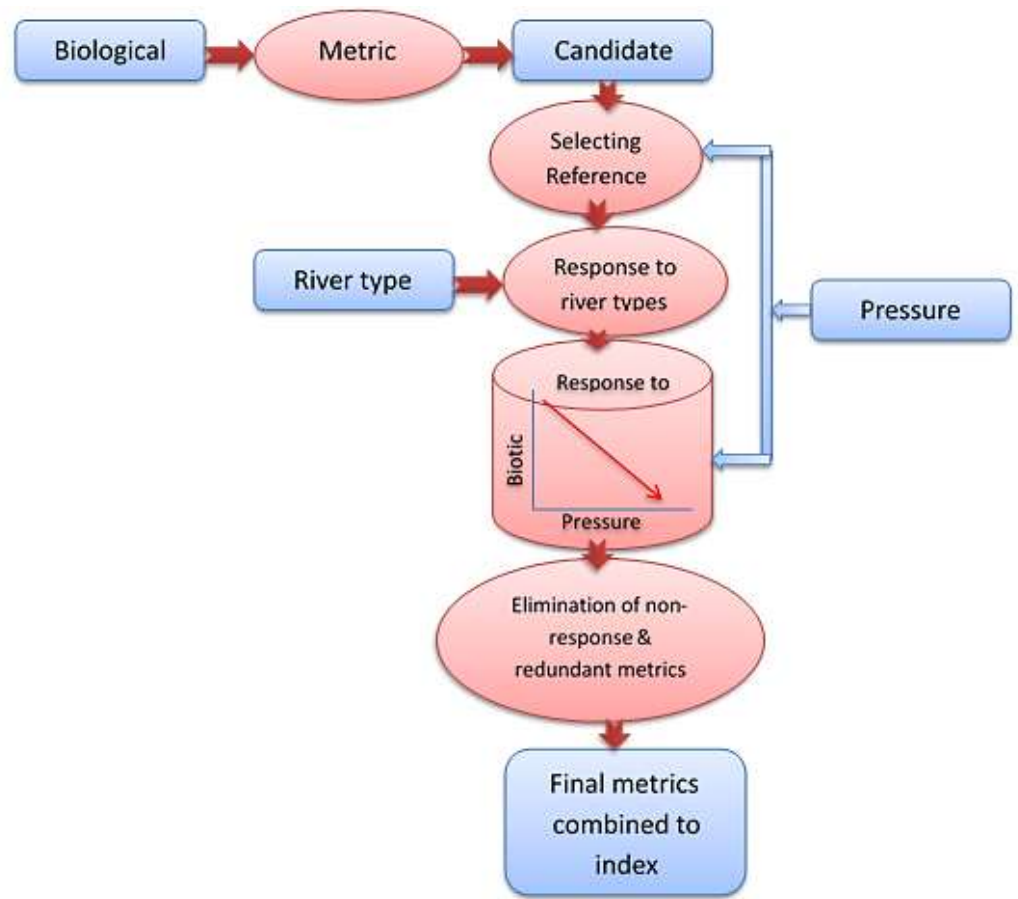

Figure 2. Key steps in developing multi-metric indices (adopted from Moog et al., 2018).

A multimetric index based on benthic macroinvertebrates for assessing the ecological status of streams and rivers was developed for some selected rivers in Ethiopia (Getachew Beneberu, 2013; Amelework Zewudu, 2017), Central and Southeast Highlands of Ethiopia (Aschalew Lakew and Moog, 2015b; Temesgen Alemneh et al, 2019), and northwestern Ethiopia (Lake Tana basin). The multimetric index (MMI) developed by Aschalew Lakew and Moog (2015b) is composed of a set of 9 core metrics chosen from an initial list of 75 potential metrics (Table 2). The core metrics were recruited based on their ability to reflect 
the level of water quality degradation, land-use changes, habitat variability, hydrological conditions, and pollution. The responses of the core metrics in this study were well correlated with anthropogenic impacts than with habitat variability. The developed index categorized sites into five river quality classes with different colors: high (blue), good (green), moderate (yellow), poor (orange), and bad (red). Its response to seasonal hydrological conditions remained constant in reference and impaired sites (agriculture, siltation, and paper mill wastes), indicating that the model was stable and could be applied to other regions of the country (Aschalew Lakew and Moog, 2015b). Similarly, Amelework Zewudu (2017) developed Lake Tana sub-basin multi-metric index (LTSBMI) (Table 2). Five core metrics were selected among 30 candidate metrics for their ability to discriminate between reference sites and sites influenced by domestic sewage from households, industries, sand mines, intensive irrigation, and riparian habitat degradation. LTSBMI was used to classify sites into five water quality classes with cutting threshold scores: very good (>72), good (65.9-72), fair (32.6-65.9), poor (16.3-32.6), and very poor (016.3).

As for rivers, IBI was also developed for wetlands found in Jimma zone using 10 metrics. IBI score categorized wetland sites into moderate and poor ecological conditions. FBI (Family level biotic index), one component of this index, was able to discriminate wetland sites that were significantly affected by organic pollution (Hayal Desta and Seyoum Mengistou, 2009). Macroinvertebrate-based multi-metric index (M-MMI) was also developed for natural wetlands found in Jimma that combined three core metrics (all family richness; the family richness of Ephemeroptera, Odonata, and Trichoptera (EOT); and \% filterer-collectors). These metrics were selected among 58 candidate metrics using the procedures and steps indicated in Figure 2. The 58 metrics were chosen from the literature and calculated using a data set of 222 samples collected from 63 sites at eight different wetlands in Jimma area (Seid Tiku et al., 2013). Redundancy analysis (RD) indicated that only three metrics were indirectly related to anthropogenic disturbance (land use, habitat alteration, hydrological modification) and water quality parameters (COD, Chl-a) and positively related to vegetation cover (Seid Tiku et al., 2013). According to Barbour et al. (1996), high richness implied the presence of physical habitat diversity, good water quality, and high availability of food resources. The developed MMI scores varied from 3 to 15, and helped categorize the wetland sites into five water quality classes: very good (14-15), good (12-13), moderate (9-11), bad (6-8), and very bad (3-5). This suggested that the M-MMI was good in discriminating impaired wetland sites from the reference sites (Seid Tiku et al., 2013). Besides, the index was negatively linked to both disturbance score and water quality index. 
Its value decreased as the disturbance score increased and water quality (despite a weak correlation) deteriorated, suggesting that this index could be suitable for detecting environmental degradation in natural wetlands (Figure 3) (Seid Tiku et al., 2013). Development of macroinvertebrate-based MMI required including appropriate and representative of several biological aspects of macroinvertebrate assemblages (Karr and Chu, 1998).
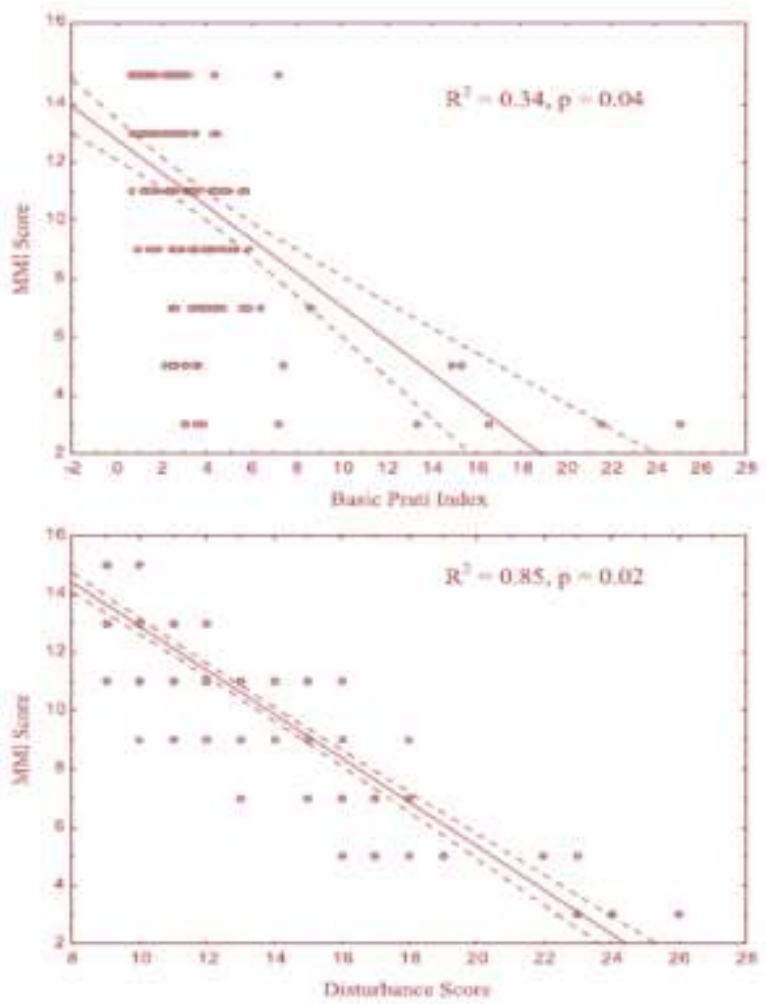

Figure 3. Correlation of multi-metric macroinvertebrates (MMI) with water and habitat quality developed using the Basic Prati index and habitat disturbance score (Seid Tiku et al., 2013).

Barbour et al. (1999) recommended core metrics should comprise at least one metric in each of the four metric categories, namely, (1) richness measures for diversity or variety of the assemblage; (2) composition measures for identity and 
dominance; (3) tolerance measures representative of the sensitivity to perturbation; and (4) trophic or habit measures for information on feeding strategies and guilds. Among the reviewed articles, only 33\% of them were met the standard criteria or protocol regarding core metrics selection in the development of a multi-metric index (Table 2). The remaining research papers $(67 \%)$ failed to include one or more representative metrics from each of the four major metric categories. The missing components of macroinvertebrate assemblage metrics were composition (Seid Tiku et al., 2013), tolerance (Seid Tiku et al., 2013, Amelework Zewudu, 2017) and feeding guild (Baye Sitotaw, 2006; Hayal Desta and Seyoum Mengistou, 2009).

Table 2. Metrics for macroinvertebrates that have been considered and evaluated for the development of an index of biotic integrity for selected streams and wetland ecosystems in Ethiopia and their predicted responses to increased levels of perturbation.

\begin{tabular}{|c|c|c|c|}
\hline SN & Metric & Metric definition & $\begin{array}{l}\text { Predicted } \\
\text { response to } \\
\text { increased } \\
\text { perturbation }\end{array}$ \\
\hline 1. & Taxa richness $^{1,3,5}$ & Total number of individual taxa & Decrease \\
\hline 2. & $\begin{array}{l}\% \\
\text { Ephemeroptera } \\
1,2\end{array}$ & Percentage composition of mayfly & Decrease \\
\hline 3. & $\%$ Plecoptera $^{1}$ & Percentage composition stonefly & Decrease \\
\hline 4. & $\%$ Trichoptera $^{1}$ & Percentage composition of caddisfly & Decrease \\
\hline 5. & $\%$ Baetidae $^{1}$ & $\begin{array}{l}\text { Percentage composition of mayfly } \\
\text { family nymphs }\end{array}$ & Decrease \\
\hline 6. & $\begin{array}{l}\% \text { EPT } \\
\text { individuals }{ }^{1,2}\end{array}$ & $\begin{array}{l}\text { Percentage composition of mayfly, } \\
\text { stonefly and caddisfly larvae }\end{array}$ & Decrease \\
\hline 7. & $\%$ Odonata $^{1}$ & $\begin{array}{l}\text { Percentage composition of damson } \\
\text { flies and dragonflies }\end{array}$ & Decrease \\
\hline 8. & $\begin{array}{l}\text { Shannon } \\
\text { diversity } \\
\text { index }^{1}\end{array}$ & $\begin{array}{l}\text { A general measure of sample diversity } \\
\text { that incorporates richness and } \\
\text { evenness }\end{array}$ & Decrease \\
\hline 9. & $\begin{array}{l}\% \text { Red } \\
\text { chironomids } 1,4\end{array}$ & $\begin{array}{l}\text { Percentage composition of blood-red } \\
\text { midge larvae }\end{array}$ & Increase \\
\hline 10. & $\%$ Diptera $^{1}$ & $\begin{array}{l}\text { Percentage composition of "true" fly } \\
\text { larvae }\end{array}$ & Increase \\
\hline 11. & $\%$ Oligochaeta $^{1}$ & $\begin{array}{l}\text { Percentage composition of aquatic } \\
\text { worms }\end{array}$ & Increase \\
\hline 12. & $\%$ Non-insect $^{1}$ & $\begin{array}{l}\text { Percentage composition of non-insect } \\
\text { BMIs }\end{array}$ & Increase \\
\hline 13. & $\begin{array}{l}\% \text { Dominant } \\
\text { taxon }^{1}\end{array}$ & $\begin{array}{l}\text { Percentage composition of the single } \\
\text { most abundant taxon }\end{array}$ & Increase \\
\hline 14. & $\mathrm{H}-\mathrm{FBI}^{1,4}$ & Hilsenhoff Family Level Biotic Index & Increase \\
\hline
\end{tabular}




\begin{tabular}{|c|c|c|c|}
\hline 15. & $\begin{array}{l}\text { \# Ephemeroptera } \\
\operatorname{taxa}^{2}\end{array}$ & Number of mayfly taxa & Decrease \\
\hline 16. & $\%$ Shredders ${ }^{2,4,5}$ & $\begin{array}{l}\text { Percent of individuals in the shredder } \\
\text { functional feeding groups }\end{array}$ & Decrease \\
\hline 17. & $\begin{array}{l}\% \text { Filters } \\
\text { feeders }^{2}\end{array}$ & $\begin{array}{l}\text { Percent of individuals in the filterer } \\
\text { Functional feeding group }\end{array}$ & Increase \\
\hline 18. & $\begin{array}{l}\text { Taxa richness of } \\
\text { EOT }^{3,5}\end{array}$ & $\begin{array}{l}\text { Family richness of Ephemeroptera, } \\
\text { Odonata, and Trichoptera together }\end{array}$ & Decrease \\
\hline 19. & $\begin{array}{l}\% \text { Filterer- } \\
\text { collectors }^{3}\end{array}$ & Percent of filterer- collectors & Decrease \\
\hline 20. & Total taxa $\#^{4}$ & Total number of taxa & Decrease \\
\hline 21. & EPT-BH $>1$ sp..$^{4}$ & $\begin{array}{l}\text { Total number of EPT (Ephemeroptera, } \\
\text { Plecoptera, and Trichoptera taxa) } \\
\text { where Baetidae and Hydropsychidae } \\
\text { taxa are considered if they consist } \\
\text { more than one taxon }\end{array}$ & Decrease \\
\hline 22. & $\mathrm{COPTE}^{4}$ & $\begin{array}{l}\text { Total number of Coleoptera, Odonata, } \\
\text { Plecoptera, Trichoptera, and } \\
\text { Ephemeroptera }\end{array}$ & Decrease \\
\hline 23. & $\%$ ЕРТ-BCH ${ }^{4}$ & $\begin{array}{l}\text { Percentage composition of EPT taxa } \\
\text { without Baetidae, Caenidae, and } \\
\text { Hydropsychidae }\end{array}$ & Decrease \\
\hline 24. & ASPT-SASS $^{4}$ & $\begin{array}{l}\text { Average South African Scoring } \\
\text { System Per Taxa }\end{array}$ & Decrease \\
\hline 25. & $\begin{array}{l}\% \text { Collector } \\
\text { gathering }\end{array}$ & $\begin{array}{l}\text { Percentage composition of gathering } \\
\text { collector individuals }\end{array}$ & Increase \\
\hline 26. & Simpson index ${ }^{5}$ & $\begin{array}{l}\text { A measure of diversity including both } \\
\text { taxa richness and an evenness } \\
\text { component }\end{array}$ & Decrease \\
\hline
\end{tabular}

NB: 1= Baye Sitotaw, 2006; 2=Ameleworku Zewudu, 2017; 3= Seid Tiku et al., 2013, 4= Aschalew Lakew and Moog, 2015b; 5= Temesgen Alemneh, 2019.

The discrepancy in the core metrics selection for the aggregated MMI could be attributed to geographical differences, the intensity of anthropogenic impacts, and protocols used for the development of the MMI (Dedieu et al., 2016; Silva et al., 2017). The use of different taxonomic resolutions could also affect the development of MMI. For instance, Aschalew and Moog (2015b) went to deeper taxonomic resolutions during the development of the MMI, which may contribute to the observed differences. In fact, using refined taxonomic resolution (genera or species) can allow the detection of multiple stressors and have better discriminating differences in biological conditions (Aschalew Lakew and Moog, 2015b). Extensive overlap of interquartile ranges, missing functional feeding groups, the difference in sampling gear, and having a zero value were 
some of the contributing factors to missing one or more representative metrics during MMI development.

\section{Biomonitoring using aquatic plants/macrophytes}

Aquatic plants are also used as sensitive tools for predicting and recognizing environmental stresses. The use of macrophytes for monitoring the status of aquatic environments (rivers, streams, lakes, and wetlands), therefore, is increasingly recognized around the world. Accordingly, plant-based monitoring and assessment indices have been developed in response to the legislative requirement around the world, mainly for the assessment of stream ecology status. Wetland ecosystem health and quality has also been monitored in the USA for a long-time using wetland vegetation as an indicator (USEPA, 2002). They are also used as a basis for comparing the reference and restored or mitigated states (Matthews et al., 2009), and as one of the three indicators of jurisdictional wetlands (Environmental Laboratory, 1987). Macrophytes are sensitive indicators due to their links to other trophic levels, which influence the delivery of ecosystem goods and services of aquatic ecosystems (Fennessy et al., 2015). Many advantages cited for using aquatic macrophyte communities for biomonitoring include susceptibility to multitude kinds of human pressure (Seo et al., 2014; Alahuhta and Aroviita, 2016), reduction of species richness in response to water level regulation and extraction (Gallardo et al., 2016).

Furthermore, macrophytes are widespread, abundant, immobile and easy to identify (Bornette and Puijaalon, 2011). Despite these advantages, ecological assessment of aquatic ecosystem health is rarely used in Ethiopia as well as in other African countries (Kennedy et al., 2016). A few attempts were reported only recently. In Kenya, for example, Achieng et al. (2014) assessed the ecological health of a small palustrine/riverine King'wal wetland, within Lake Victoria basin using the plant index of biotic integrity (PIBI). They concluded that the vegetation metrics used could effectively delineate different levels of anthropogenic disturbances affecting the wetland area. Kennedy et al. (2016) also developed a new biomonitoring protocol called the Zambian macrophyte trophic ranking scheme (ZMTR) to assess the trophic status of tropical southern African rivers. ZMTR was able to accurately indicate the trophic status of $83.1 \%$ of the study sites of rivers in Zambia and Botswana. In Ethiopia, only a single study tried to develop a plant-based index of biotic integrity (PIBI) as an alternative management tool in Jimma highlands (Admasu Moges et al., 2016). The results showed that macrophytes are dependable and sensitive indicators for bioassessment purposes, which discriminated reference and impacted sites in the study area. The development of a multi-metric index involves considering as 
numerous as possible potential metrics searching from the literature. Admasu Moges et al. (2016) chose a total of 35 potential plant community indicators. Of these, 13 relevant metrics were incorporated based on their responsiveness to anthropogenic perturbations. After avoiding redundant metrics using the Spearman correlation coefficient, they selected only 4 core metrics for developing the final index (PIBI). The core metrics included a $\%$ cover of native species, sensitive species richness, tolerant species richness, and \% of shrub species richness. They reported that among the four metrics, sensitive species richness was able to discriminate impaired sites from the reference sites better than any other metrics. A strong correlation was thus reported between the core metrics and environmental variables (Table 3). A negative but significant correlation was also observed between PIBI and the majority of physicochemical variables (Admasu Moges et al., 2016).

Table 3. Spearman's rank order correlations between core metrics and mean water quality parameters (Admasu Moges et al., 2016).

\begin{tabular}{llllll}
\hline \multirow{2}{*}{$\begin{array}{l}\text { Core metrics } \\
\text { (of species) }\end{array}$} & $\begin{array}{l}\text { Water } \\
\text { temperat } \\
\text { ure }\end{array}$ & $\begin{array}{l}\text { Electrical } \\
\text { conductivity }\end{array}$ & $\begin{array}{l}\text { Nitrate } \\
\text { s } \\
/ \mathbf{N O}^{-}\end{array}$ & $\begin{array}{l}\text { Chlorine } \\
/ \mathbf{C l}^{-}\end{array}$ & $\begin{array}{l}\text { Total } \\
\text { suspended } \\
\text { solids/TSS }\end{array}$ \\
\hline Natives $(\%)$ & -0.20 & $-0.34^{*}$ & -0.25 & $-0.46^{*}$ & $0.39^{*}$ \\
Sensitive $\dagger$ & $-0.68^{*}$ & $-0.36^{*}$ & -0.20 & $-0.44^{*}$ & -0.18 \\
Tolerant $\dagger$ & $-0.43^{*}$ & -0.06 & $-0.40^{*}$ & $-0.13^{*}$ & $-0.28^{*}$ \\
Shrubs $(\%) \dagger$ & -0.05 & 0.44 & -0.28 & 0.02 & 0.01 \\
\hline
\end{tabular}

*Significant difference at $\mathrm{p}<0.05 ; \dagger$ stands for richness.

Yetneberk Kassaye et al. (2016) also investigated the concentration of trace elements in aquatic macrophytes in Ethiopian Rift Valley lakes aiming to evaluate the pollution levels of these lakes. They found macrophyte species Aeschynomene elaphroxylon $\left(1.6 \times 10^{3} \mathrm{mg} \mathrm{kg}^{-1} \mathrm{dw}\right.$, Lake Ziway) and Eichhornia crassipes $\left(1.2 \times 10^{3} \mathrm{mg} \mathrm{kg}^{-1} \mathrm{dw}\right.$, Lake Koka) accumulated high concentrations of Mn as compared to the lakes' water and sediment. Similarly, Girma Tilahun and Tigist Ashagre (2012) reported that Typha latifolia accumulated higher heavy metals $(\mathrm{Pb}, \mathrm{Cd}, \mathrm{Hg})$ concentration than Schoenoplectus corymbosus. $\mathrm{Zn}$ and $\mathrm{Cr}$ were also found in high concentrations in both macrophyte species compared to other heavy metals. Yezbie Kassa (2016) reported that Yitamot wetland (in the upper Blue Nile basin) had removed $99 \%$ of the nutrients (nitrate and total nitrogen) and metals (such as Mn) from wastes contaminated by Bahir Dar city municipality and Bahir Dar University (Peda campus). This is mainly attributed to the uptake by dominant macrophytes (C. papyrus, C. digitatus, P. karka, Spaeranthus suaveolens, Hydrocotyle ranunculoides, and Echinochloa stagnina) inhabiting the wetlands (Yezbie Kassa, 2016). Macrophytes accumulate more 
trace elements gradually in their leaves during the growing season (Schierup and Larsen, 1981). A study on tissue nutrient (TN and TP) contents of some macrophyte species (T. latifolia, C. papyrus, and P. karka) in Lake Tana confirmed that their nutrient composition differed among plant species and their body parts (Yezbie Kassa, 2016). The leaves of the three species had higher total nitrogen content than their stems. This may be attributed to the metabolic activity of the tissues. Leaves are the place where photosynthesis takes place and thus are more active, whereas roots and stems are usually involved in storage, transporting water, and nutrients ( $\mathrm{Yu}$ et al., 2014). The change in the nutrient content of water among places may also contribute to the variability of plant tissue nutrient levels in both plant species and seasons. These results suggest that macrophytes are important in guarding aquatic ecosystems against pollution by improving water quality through removing heavy metals and nutrients, and therefore, they could serve as potential indicators of pollution and phytoremediation. Apart from ecosystem degradation, trace element accumulation, however, has a grave consequence on the health of human and animal populations that are involved along the food chain of the lakes. Herbivorous animals may bioaccumulate trace elements in their body through eating these macrophyte plants accumulating trace elements, which may perhaps biomagnify at higher trophic levels in the food chain. For instance, $A$. elaphroxylon is a multipurpose wetland shrub around Lake Ziway and its wilted leaves have been used as feed for small ruminants (Kaitho et al., 1996). The concentration of $\mathrm{Mn}$ in $A$. elaphroxylon from Lake Ziway exceeded the maximum tolerable level of Mn for animal feed (Ammerman et al., 1980).

\section{Biomonitoring using diatoms}

The diversity of diatoms is substantially higher in freshwater ecosystems compared to other algal groups (Stoermer and Smol, 1999). They are important primary producers of aquatic systems and playing major roles in food webs and biogeochemical cycles (Stevenson et al., 2010). The change in diatom biomass and community composition can be used to infer the level of water quality degradation and environmental changes, which could ultimately be used to assess the physical, chemical, and biological integrity of aquatic ecosystems. They provide a quick response to environmental disturbances (Figure 4) such as $\mathrm{pH}$, conductivity and nutrients (Bennion and Smith, 2000; Potapova and Charles, 2003), eutrophication (Kitner and Poulícková, 2003), global warming problems (Leelahakriengkrai and Peerapornpisal, 2010) and physical habitat alterations (Stevenson, 2014). Using diatoms for Ecotoxicology is also advantageous because it allows us to investigate the influence of contaminants at various levels of ecological organization ranging from the individual cell to community levels 
(Debenest et al., 2013). Furthermore, they are easy for sampling, preserving, observing live frustules, and identifying using acid-cleaned frustules (Pandey and Bergey, 2016; Pandey et al., 2018).

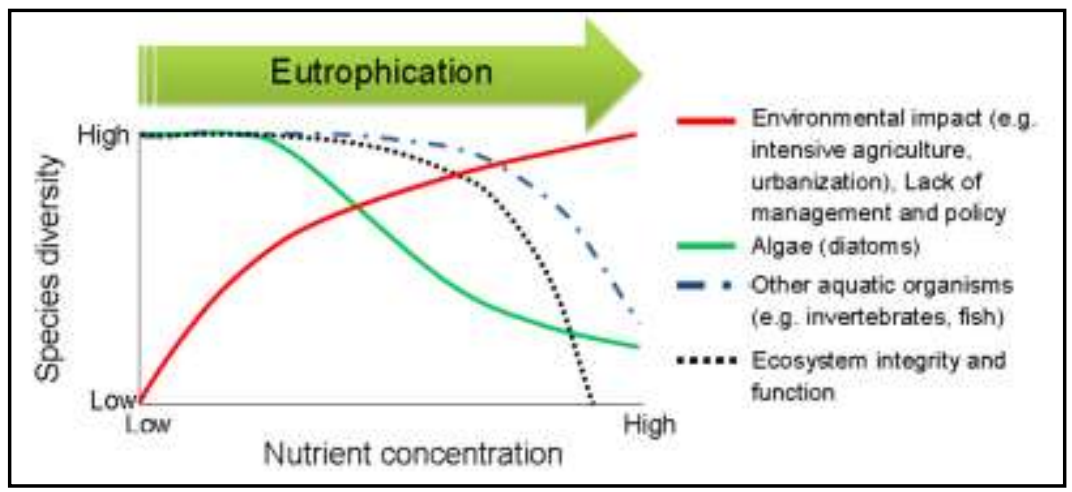

Figure 4. Anthropogenic impacts on aquatic biodiversity, ecological integrity, and functioning of aquatic ecosystems as the changes can be monitored using diatoms (Dalu and Froneman, 2016).

As a result, many potential biotic indices of diatoms have been developed around the world: trophic diatom indices (TDI), pollution sensitivity indices (IPS), generic diatom indices (GDI), and trophic diatom indices (TDIL) for lakes (Taylor et al., 2007a; Blanco et al., 2004). Owing to its ubiquity, diatom assemblages and pollution indices are also an integral part of many stream assessment programs worldwide (Simkhada et al., 2006). They are even used in paleolimnology to infer past and future conditions of aquatic ecosystems (Rühland, 2003; Levy, 2017).

Bioassessments of short- and long-term environmental quality changes using diatoms are growing in Africa (De La Rey et al., 2004; Taylor et al., 2007b; De La Rey et al., 2008; Abebe Beyene et al., 2009; Bere and Tundisi, 2010; Lang et al., 2012; Bere and Mangadze, 2014). However, the diatoms biomonitoring of water resources in East Africa, including Ethiopia, is very limited. A few studies exist based on benthic diatoms were performed in Kenyan rivers for assessing their health conditions (Ndiritu et al., 2003; Ndiritu et al., 2006; Triest et al., 2012), and researchers were able to demonstrate that appropriate watershed management tools can be successfully developed using diatom communities within aquatic ecosystems. 
Abebe Beyene et al. (2009) was the first who attempted to apply diatoms as indicators of severe water pollution in Kebena and Akaki rivers in Addis Ababa, Ethiopia. They used 9 diatom metrics namely; Abundance, Richness, Evenness, Diversity, Simpson diversity, Alpha diversity, IPS (specific pollution-sensitive index), IBD (diatom biological index), and \% PT (percent pollution-tolerant taxa). Their results showed that species diversity was higher at the upstream sites than downstream sites. Both IPS and IBD revealed a similar pattern that upstream sites had better ecological quality than their corresponding downstream sites. Biochemical oxygen demand (measured up to a level of $1250 \mathrm{mg} / \mathrm{l}$ ) and nutrients (phosphate and nitrogen) were found significantly higher in the downstream river sites (Abebe Beyene et al., 2009), which corroborated the results of the diatom biomonitoring. The diatom species Achnantidium minutissima (low nutrient indicator) was most abundant at the upstream sites. Its abundance was strongly correlated with the gradient of primary habitat quality. They measured habitat quality using the qualitative habitat evaluation index (QHEI) based on Rankin's (2006) classes. The index indicated that most sites were categorized into poor quality classes, reflecting high habitat degradation and loss in the local rivers. The RDA ordination of diatom species and environmental variables classified the sampling sites in ascending order of pollution level from the relatively clean upstream sites to the progressively more polluted downstream sites (Abebe Beyene et al., 2009). Alemayehu Negassa (2016) also reported that diatom species richness declined within the downstream sites in response to increased conductivity, nutrient loads, organic pollution, and contaminations with heavy metals mainly cadmium. Moreover, diversity indices, evenness, dominance, Trophic diatom index (TDI), Saprobic index (SI), and community lost index (CLI) indicated an increased water quality deterioration at downstream sites. Taffere Addis (2008) also reported the same result for the same river. A similar result was also reported from Beijing, China (Chen et al., 2016). They used a range of diatom structural metrics, including species richness, Shannon diversity, species evenness, and Simpson diversity. These metrics were able to discriminate urban downstream from reference and urban upstream sites. All study sites had different diatom species composition. However, Achnanthidium minutissima, Staurosira construens and Pseudostaurosira brevistriata, and Nitzschia palea species were dominant at the reference, urban upstream, and urban downstream sites, respectively. The relative abundance of these species was positively correlated with some environmental variables (potassium ion, electrical conductivity, total nitrogen, chloride ion, and $\mathrm{pH}$ ) in urban downstream samples; whereas water temperature and fluorine ion were correlated with reference and urban stream diatom composition. Thus, the researchers were able to demonstrate that diatom species composition was more sensitive to urbanization 
than the water's physico-chemical parameters, and implying diatom assemblage structure metrics have more accurately assessed water quality.

Diatoms appeared to be better indicators of urban stream conditions (Taffere Addis, 2008; Abebe Beyene et al., 2009; Chen et al., 2016) compared to macroinvertebrates. A comparative study of diatoms and macroinvertebrates as indicators of severe water pollution in Ethiopian urban rivers by Abebe Beyene et al. (2009) showed that macroinvertebrate species composition was more affected by the stream physical habitat quality and water chemistry than diatoms. Consequently, macroinvertebrates were completely absent in the majority of the polluted sites, especially when the dissolved oxygen concentration was very low. At these stream sites, diatoms were more accurately identified gradient of pollution than the corresponding macroinvertebrates.

\section{CHALLENGES IN THE USE OF BIOLOGICAL MONITORING IN ETHIOPIA}

The commitment of the Ethiopian government with regard to water resources and freshwater ecosystem conservation is promising as reflected from a wide range of policies, legislations, and laws. However, their implementation and enforcement by the authorities at different levels for safeguarding aquatic ecosystems against physical degradation and chemical pollution is very low. Regulatory authorities involved in environmental management rarely apply biological data for monitoring purposes. The country doesn't, therefore, recognize the importance of biological organisms for better management and conservation of freshwater ecosystems. The concept of bioassessment is not yet an integral part of the Ethiopian water resource management policy. Lack of legislation and standard protocols for sampling and analysis of macroinvertebrates further complicated its implementation. Thus, neither biotic indices (multi-metric methods) nor multivariate approaches have been used so far by government environmental monitoring organizations. As a result, researchers are using non-standardized protocols and different methodologies for sampling and processing of macroinvertebrate samples (Table 4), which is difficult to reach at a conclusive result. For instance, net mesh size used is not uniform (which varies from 250 to $000 \mu \mathrm{m}$ ). According to Buss et al. (2015), the smallest size of macroinvertebrates caught is determined by the size of the mesh. Consequently, the calculation of biotic metrics will be affected if abundance is used as input data because a sampler with a very small size mesh can collect more organisms. 
Table 4. Comparison of methodologies for the collection and processing of benthic macroinvertebrates as indicator organisms for developing biotic indices in Ethiopia.

\begin{tabular}{|c|c|c|c|c|}
\hline Author & $\begin{array}{l}\text { Sampling } \\
\text { sites }(\%)\end{array}$ & $\begin{array}{l}\text { Sampling protocol, net } \\
\text { type, and net mesh size }\end{array}$ & Location & $\begin{array}{l}\text { Metric } \\
\text { scoring } \\
\text { methods }\end{array}$ \\
\hline $\begin{array}{l}\text { Baye } \\
\text { Sitotaw } \\
(2006)\end{array}$ & 15 & $\begin{array}{l}\text { Surber sampler (sampler } \\
(\text { mesh size }=500 \mu \mathrm{m}, \\
\left.\text { sampling area }=0.9 \mathrm{~m}^{2}\right) \text {; } \\
\text { D-frame net with no } \\
\text { mesh size, Scoop net, } \\
\text { multihabitat approach } \\
\text { within } 200 \mathrm{~m} \text { reach }\end{array}$ & $\begin{array}{l}\text { Abay, Baro, } \\
\text { Omo-Ghibe, } \\
\text { and Awash } \\
\text { basins }\end{array}$ & Continuous \\
\hline $\begin{array}{l}\text { Solomon } \\
\text { Akalu et al. } \\
\text { (2011) }\end{array}$ & 8 & $\begin{array}{l}\text { Surber sampler (mesh } \\
\text { size }=500 \mu \mathrm{m} \text {, sampling } \\
\text { area }=0.9 \mathrm{~m}^{2} \text { ); Scoop net } \\
\text { sampled during dry } \\
\text { season in riffles \& pools }\end{array}$ & $\begin{array}{l}\text { Greater Akaki } \\
\text { river, Addis } \\
\text { Ababa }\end{array}$ & Continuous \\
\hline $\begin{array}{l}\text { Solomon } \\
\text { Akalu } \\
(2017)\end{array}$ & 12 & $\begin{array}{l}\text { Surber sampler }(\text { area }= \\
0.09 \mathrm{~m}^{2}, \text { mesh size }=500 \\
\mu \mathrm{m}) ; \text { Scoop net, brush for } \\
\text { attached organisms.; wet } \\
\& \text { dry season in riffles } \& \\
\text { pools of } 100 \mathrm{~m} \text { reach }\end{array}$ & $\begin{array}{l}\text { Greater and } \\
\text { Little Akaki } \\
\text { rivers }\end{array}$ & $\begin{array}{l}\text { SASS } 5 \\
\text { and } \\
\text { ETHbios }\end{array}$ \\
\hline $\begin{array}{l}\text { Hayal } \\
\text { Desta and } \\
\text { Seyoum } \\
\text { Mengistou } \\
(2009)\end{array}$ & 3 & $\begin{array}{l}\text { D-frame dip nets with } \\
1000 \mu \mathrm{m} \text { mesh size; } \\
\text { samples were taken } \\
\text { during the dry season and } \\
\text { at high rainfall } \& \\
\text { vegetation growth months } \\
\text { (April, May) }\end{array}$ & $\begin{array}{l}\text { Jimma town } \\
\text { wetlands }\end{array}$ & $\begin{array}{l}\text { Hilsenhoff } \\
\text { Family } \\
\text { Level } \\
\text { Biotic } \\
\text { Index } \\
\text { (FBI) }\end{array}$ \\
\hline $\begin{array}{l}\text { Mekedes } \\
\text { Hone } \\
(2016)\end{array}$ & 4 & $\begin{array}{l}\text { D-frame net with mesh } \\
\text { size } 500 \mu \mathrm{m}\end{array}$ & $\begin{array}{l}\text { Blue Nile } \\
\text { river head }\end{array}$ & $==$ \\
\hline $\begin{array}{l}\text { Amelework } \\
\text { Zewudu } \\
(2017)\end{array}$ & 20 & $\begin{array}{l}\text { Surber sampler }(30 \times 30 \\
\mathrm{cm}) \text {; net mesh size } 1000 \\
\mu \mathrm{m}-\text {-riffle sampling } \\
\text { D-frame net-pool } \\
\text { sampling }\end{array}$ & $\begin{array}{l}\text { Streams and } \\
\text { rivers in Lake } \\
\text { Tana sub- } \\
\text { basin }\end{array}$ & $\begin{array}{l}\text { Continuous } \\
\text { scoring }\end{array}$ \\
\hline $\begin{array}{l}\text { Aschalew } \\
\text { Lakew and } \\
\text { Moog } \\
(2015 b)\end{array}$ & 104 & $\begin{array}{l}\text { Standard hand net with } \\
25 \times 25 \mathrm{~cm} \text { and mesh size } \\
500 \mu \mathrm{m}, \text { multi-habitat } \\
\text { approach }\end{array}$ & $\begin{array}{l}\text { Streams in } \\
\text { Awash, } \\
\text { Wabe- } \\
\text { Shebelle, } \\
\text { Genale, and } \\
\text { Rift Valley } \\
\text { basins }\end{array}$ & $\begin{array}{l}\text { Continuous } \\
\text { scoring }\end{array}$ \\
\hline
\end{tabular}


Workiye Worie et al.

\begin{tabular}{|c|c|c|c|c|}
\hline $\begin{array}{l}\text { Seid Tiku } \\
\text { et al. } \\
(2013)\end{array}$ & 63 & $\begin{array}{l}\text { Rectangular frame net } \\
20 \times 30 \mathrm{~cm} \text { with } 300 \mu \mathrm{m}\end{array}$ & $\begin{array}{l}\text { Five riverine } \\
\text { wetlands and } \\
\text { three } \\
\text { floodplain } \\
\text { wetlands, } \\
\text { Gilgel Ghibe } \\
\text { watershed }\end{array}$ & $\begin{array}{l}\text { Continuous } \\
\text { scoring }\end{array}$ \\
\hline $\begin{array}{l}\text { Amare } \\
\text { Mezgebu et } \\
\text { al. (2019) }\end{array}$ & 9 & $\begin{array}{l}\text { Square frame hand net } \\
\text { with } \\
25 \times 25 \mathrm{~cm} \text { and mesh size } \\
\text { of } 500 \mu \mathrm{m} \text {, multihabitat } \\
\text { sampling scheme in } 100 \\
\text { m reach; sampling units } \\
\text { consider substrate types }\end{array}$ & $\begin{array}{l}\text { Four streams } \\
\text { around Sebeta } \\
\text { town exposed } \\
\text { to various } \\
\text { anthropogenic } \\
\text { activities }\end{array}$ & $\begin{array}{l}\text { SASS } 5 \\
\text { and } \\
\text { ETHbios }\end{array}$ \\
\hline $\begin{array}{l}\text { Mesfin } \\
\text { G/Hiwot et } \\
\text { al. }(2017)\end{array}$ & 34 & $\begin{array}{l}\text { Rectangular frame kick } \\
\text { net with } 50 \times 33 \mathrm{~cm} \text { frame, } \\
\text { mesh size } 250 \mu \mathrm{m}\end{array}$ & $\begin{array}{l}\text { Gilgel Ghibe } \\
\text { watershed }\end{array}$ & $==$ \\
\hline $\begin{array}{l}\text { Temesgen } \\
\text { Alemneh et } \\
\text { al. }(2017 \text {; } \\
\text { 2019) }\end{array}$ & 36 & $\begin{array}{l}\text { D-frame net with a mesh } \\
\text { size of } 300 \mu \mathrm{m} \text {; sampling } \\
\text { taken during dry and wet } \\
\text { seasons in } 10 \mathrm{~m} \text { stretch } \\
\text { micro- and meso-habitats }\end{array}$ & $\begin{array}{l}\text { Choke } \\
\text { mountain, } \\
\text { Chemoga } \\
\text { river }\end{array}$ & $==$ \\
\hline
\end{tabular}

Habitat evaluation, sampling procedures/protocols, including metric scoring methods were some of the variants observed among the researchers. Lack of identification keys is another serious problem as the majority of the researchers used identification keys developed for temperate regions. It is well documented that Ethiopia is rich in invertebrate diversity and above all with a high degree of endemism (Seyoum Mengistou, 2006). The majority of the studies conducted in Ethiopia identified macroinvertebrates to the family level, though few studies have tried to combine both genus and species levels (e.g., Getachew Beneberu, 2013; Aschalew Lakew and Moog, 2015b). Despite exercising taxonomic resolutions at a lower resolution is expensive and time-consuming, the degree of pollution and aquatic environmental conditions are reflected very well at the genera and species levels. It is recommended that the index to be developed in the tropics should depend on identification to lower taxonomic level resolution that can provide accurate and precise data (Elias et al., 2014). The number of sampling sites also varied and ranged from 3 to 104 (Table 5). How many sample sizes and areas are sufficient for representing invertebrate communities in a given ecosystem considered for a study are important questions. For example, the value of taxon richness is extremely influenced by many interacting factors such as the size of the sample area, the diversity of habitats visited, antecedent flow as well as the number of individuals identified and the taxonomic level of identification 
(Wagenhoff et al., 2016). The biological data and their corresponding habitat, physical, and chemical parameters generated through inconsistent methods and protocols will compromise the reliability and quality of the information synthesized. Hence, consistency in the collection and processing of data is crucial for comparison across sites or years.

Apart from the laws and protocols, the absence of identification keys and expertise hampered the development of biomonitoring tools in the country. Almost all the papers examined in the present review use guides and keys for macroinvertebrate identification that have been applied in the United States of America (USA), Europe, Australia, and South Africa, which may limit the credibility of the assessments. In fact, Ochieng et al. (2019) reported that East African researchers are facing taxonomic challenges while monitoring freshwater bodies using macroinvertebrates. They recommended the urgent development of identification guides that are based on local species to ensure the development of biotic metrics important for intended purposes. In other countries, the development of bioassessment tools is legislation driven by supporting researcher funds, capacity building, field and lab equipment, and creating a conducive working environment. Unavailability of these kinds of support via legislation in our country certainly discourages researchers from developing monitoring tools and advancing the system to a higher level. Moreover, even in the few studies, the approaches utilized for bioassessment are very traditional, but others are usually complemented using molecular approaches. In the current situation, obtaining a reference condition for a basin in Ethiopia is very challenging as most areas are easily accessible to humans. Such problems can be solved using historical data/baseline information or else from paleolimnology, which is rarely available in Ethiopia. Lack of this information would be a major deterrent to the development of metrics for assessing water resources in the country.

Generally, people have been doing researches related to biomonitoring based solely on individual interest facing all the above grand constraints. The efforts are appreciated, however, the bioassessments conducted in the country may not be comparable in terms of results across seasons, sites, and ecoregions. These pitfalls will limit the anticipated information from the studies. According to Clarke and Hering (2006), the utilization of inconsistent sampling tools and protocols might introduce erroneous and uncertainty during data collection even in the same climatic regions, resulting in undependable biomonitoring results. The application of a standardized protocol is, therefore, a prerequisite to obtaining quality data for the development of biological indices to monitor water resources. In line with this, De Pauw et al. (2006) underlined that sampling 
equipment, field sampling technique, processing of organisms, level of taxonomic resolution with taxonomic references, and index calculation should be defined and standardized.

\section{CONCLUSION AND FUTURE DIRECTIONS}

The progress of developing biomonitoring tools in Ethiopia is promising as reflected by several attempts in different water bodies initiated by interested individuals. However, these efforts have been hindered by the unavailability of standardized methods, protocols, and identification keys; absence of biological monitoring experts; lack of logistics and equipment as well as very low attention by the government. Furthermore, most studies are skewed towards the indicator values of macroinvertebrates, focusing more on stream and river ecosystems. Macrophytes, fish, and to a lesser extent algae/diatom seem to be neglected biological entities in Ethiopia in particular and the whole of Africa in general. This may be related to the availability of resources, and difficulty in sampling and identification. In Africa, for instance, diatom-based indices are not commonly used owing to the absence of capacity and training in diatom taxonomy, which resulted from limited funding and job opportunities (Bere, 2016). The facilities and expertise required to process and analyze diatoms in most African institutions are completely absent (Dalu and Froneman, 2016). Although bioassessments conducted in the country are limited, few studies were able to successfully indicate the intensity of degradation and aquatic ecosystem health including the sources of the stressors. The major stressors include agricultural activities, catchment degradation, untreated domestic and industrial wastes, siltation, habitat quality deterioration, water abstraction, flow impairment, etc. We, therefore, encourage the use of biological indicators as they are reliable, cost-effective, and provide an integrated assessment of ecosystem health status compared to the traditional approach (physico-chemical analyses).

Environmental and water management efforts should concentrate on the specific nature of the damage, along with enforcement of existing wastewater discharge standards, restoration of degraded habitats, and mitigation of further degradation, based on accurate assessment and interpretation of component metrics and an apprehension of the amounts and types of human interference. Thus, policies governing the environment and water should also consider aquatic ecosystem protection and conservation as key components in water resources and ecosystem management (Masese et al., 2013; Mangadze et al., 2019). 


\section{RECOMMENDATIONS}

Biotic indices could be developed with less cost and effort, but they are efficient tools to assess the health of aquatic environments. They are very appropriate for developing countries such as Ethiopia, where the allocation of budget and materials are inadequate for collecting continuous time series physicochemical data. To advance the use of biomonitoring in our country the policy issues, financial and technical challenges should be resolved, and the following recommendations are forwarded:

(1) Government agencies who work related to water and aquatic ecosystems should recognize the importance of biomonitoring and encourage its utilization, support it by ratifying relevant laws, legislations, and standard protocols including finance and materials. Aquatic ecologists and environmentalists who are work in the area of biomonitoring should increase the awareness of policy and decision-makers, and the public at large regarding the importance of biological indices for better management of water resources preparing symposiums, policy briefs, and leaflets in vernacular languages. Moreover, we need to keep on promoting the Regional and Federal Governments to include the bioassessment program in Water Resources Management Policy and Proclamation;

(2) The inventory and description of native floras and faunas, including their ecology, should be worked out accompanied by identification keys and guides that can allow easy taxonomic identification. Until the flora and fauna are better known, biomonitoring will remain unutilized;

3) Tolerance values for biological organisms (macroinvertebrates, diatoms, macrophytes) and their corresponding indices should be developed based on different ecoregions of the country, possibly using qualitative toxicological tests or by direct gradient-analysis to identify the various environmental optima for various taxa;

(4) Ecoregion-based key biological metrics from families containing high diversity should be identified for developing a new biomonitoring index;

(5) Universities and research institutes should be encouraged for the development of appropriate monitoring tools using biological organisms (Macroinvertebrates, Diatoms, and Macrophytes) to assess water quality changes and habitat degradation; 
(5) Technical manpower that is good at identifying and understanding the ecology of organisms (floristic and fauna) should be trained through short- and long-term training programs and their number should be increased in government agencies and

(6) Biomonitoring should be included as a separate course that should be given at least at the postgraduate level.

\section{ACKNOWLEDGMENTS}

We wish to thank the editors and two anonymous reviewers for the helpful comments on the earlier version of this manuscript. We also appreciate the internet service provided by Bahir Dar University for searching the literature.

\section{REFERENCES}

Abebe Beyene, Taffere Addis, Demeke Kifle, Worku Legesse., Kloos, H and Triest, L. (2009). Comparative study of diatoms and macroinvertebrates as indicators of severe water pollution: Case study of Kebena and Akaki rivers in Addis Ababa, Ethiopia. Ecological Indicators 9: 381392.

Abebe Beyene, Yared Kassahun, Taffere Addis, Fassil Assefa, Aklilu Amsalu, Worku Legesse, Kloos, H and Triest, L. (2012). The impact of traditional coffee processing on river water quality in Ethiopia and the urgency of adopting sound environmental practices. Environmental Monitoring and Assessment 184: 7053-7063.

Abebe Getahun and Stiassny, M.L.J. (1998). The Freshwater biodiversity crisis: The case of the Ethiopian fish fauna. SINET: Ethiopian Journal of Science 21: 207-230.

Abrehet Kahsay, Shewit Gebremedhin, and Belayneh Ayele (2015). Effects of Bahir Dar Textile Factory Effluents on the Water Quality of the Head Waters of Blue Nile river, Ethiopia. International Journal of Analytical Chemistry: http://dx.doi.org/10.1155/2015/905247.

Achieng, A.O., Raburu, P.O., Okinyi, L and Wanjala, S. (2014). Use of macrophytes in the bioassessment of the health of King'wal Wetland, Lake, Victoria Basin, Kenya. Aquatic Ecosystem Health and Management 17: 129-136.

Admasu Moges, Abebe Beyene, Ensermu Kelbessa, Seid Tiku and Argaw Ambelu (2016). Development of a multimetric plant-based index of biotic integrity for assessing the ecological state of forested, urban and agricultural natural wetlands of Jimma Highlands, Ethiopia. Ecological Indicators 71: 208-217.

Alahuhta, J and Aroviita, J. (2016). Quantifying the relative importance of natural variables, human disturbance and spatial processes in ecological status indicators of boreal lakes. Ecological Indicators 63: 240-248.

Alemayehu Negassa (2016). Spatial and temporal trends in the water quality of Huluka river, Ethiopia: An assessment using selected physicochemical and biological methods. PhD Dissertation, Addis Ababa University, 166 pp.

Amare Mezgebu, Aschalew Lakew, Brook Lemma and Getachew Beneberu (2019). The potential use of chironomids (Insecta: Diptera) as bioindicators in streams and rivers around Sebeta, Ethiopia. African Journal of Aquatic Science 44(4), DOI: 10.2989/1608'914.2019.1650711. 
Amelework Zewudu (2017). Development of multi-metric index for assessing the ecological integrity of some selected rivers and streams in the north eastern part of Lake Tana sub-basin. MSc Thesis, Bahir Dar University, Ethiopia, 86 pp.

Ammerman, C., Fontenot, J., Fox, M., Hutchinson, H., Lepore, P., Stowe, H., Thomson, D and Ullrey, D. (1980). Mineral Tolerance of Domestic Animals. National Academy of Science, Washington, D.C.

Argaw Ambelu, Lock, K and Goethals, P. (2010). Comparison of modelling techniques to predict macroinvertebrate community composition in rivers of Ethiopia. Ecological Informatics 5: 147152.

Aschalew Lakew and Moog, O. (2015a). Benthic macroinvertebrates based new biotic score "ETHbios" for assessing ecological conditions of highland streams and rivers in Ethiopia. Limnologica 52: 11-19.

Aschalew Lakew and Moog, O. (2015b). A multimetric index based on benthic macroinvertebrates for assessing the ecological status of streams and rivers in Central and Southeast highlands of Ethiopia. Hydrobiologia 751: 229-242.

Assefa Wosnie and Ayalew Wondie (2014). Assessments of downstream impact of Bahir Dar tannery effluent on the head of Blue Nile river using macroinvertebrates as bioindicators. International Journal of Biodiversity and Conservation 6(4): 342 - 350 .

Ayalew Wondie (2010). Current land use practices and possible management strategies in shore area wetland ecosystem of Lake Tana: Towards improving livelihoods, productivity and biodiversity conservation. In: Management of Shallow Water Bodies for Improved Productivity and Peoples' Livelihoods in Ethiopia, pp. 7-9 (Seyoum Mengistou and Brook Lemma, eds.). Addis Ababa, Ethiopia: Addis Ababa University Press.

Ayalew Wondie (2018). Ecological conditions and ecosystem services of wetlands in the Lake Tana Area, Ethiopia. Ecohydrology and Hydrobiology 18: 231-244.

Ayenew Gezie, Wassie Anteneh, Eshete Dejen and Seid Tiku (2017). Effects of human-induced environmental changes on benthic macroinvertebrate assemblages of wetlands in Lake Tana Watershed, Northwest Ethiopia. Environmental Monitoring and Assessment 189: 152, DOI 10.1007/s10661-017-5853-2.

Barbour, M.T., Gerristen, J., Snyder, B.D and Stribling, J.B. (1999). Rapid bioassessment protocols for use in streams and wadable rivers: Periphyton, benthic macroinvertebrates and fish. US Environmental Protection Agency; Office of Water, Washington, D.C.

Barbour, M.T., Gerritsen, J., Griffith, G.E., Frydenborg, R., McCarron, E. White, J. S and Bastian, M.L. (1996). A frame work for biological criteria for Florida streams using benthic macroinvertebrates. Journal of North America. Benthological Society 15: 185-211.

Barbour, M.T., Plafkin, J.L., Bradley, B.P., Graves, C. G and Wisseman, R.W. (1992). Evaluation of EPA's Rapid Bioassessment benthic metrics: metric redundancy and variability among reference stream sites. Environmental Toxicology and Chemistry 11: 437-449.

Bartram, J and Balance, R. (1996). Water quality monitoring: a practical guide to the design and implementation of fresh water quality studies and monitoring programs. UNEP, Taylor and Frances, London.

Baye Sitotaw (2006). Macroinvertebrate assemblage structure in relation to and use types and pollution in some Ethiopian rivers. MSc. Thesis, Addis Ababa University, Ethiopia. 132 pp.

Bennion, H.B and Smith, M.A. (2000). Variability in water chemistry of shallow ponds in southeast England, with special reference to the seasonality of nutrients and implications for modelling trophic status. Hydrobiologia 436: 145-158.

Bere, T. (2016). Challenges of diatom-based biological monitoring and assessment of streams in developing countries. Environmental Science and Pollution Research 6: 5477-5486.

Bere, T and Mangadze, T. (2014). Diatom communities in streams draining urban areas, community structure in relation to environmental variables. Journal of Tropical Ecology 55: 271-281.

Bere, T and Tundisi, J.G. (2010). Biological monitoring of lotic ecosystems: the role of diatoms. Brazilian Journal of Biology 70: 493-502. 
Birk, S., Bonne, W., Borja, A., Brucet, S., Courrat, A., Poikane, S and Hering, D. (2012). Three hundred ways to assess Europe's surface waters: An almost complete review of biological methods to implement the water Framework Directive. Ecological Indicators 18: 31-41.

Blanco, S., Ector, L and Bécares, E. (2004). Epiphytic diatoms as water quality indicators in Spanish shallow lakes. Vie Milieu 54(2-3): 71-79.

Bonada, N., Prat, N., Resh, V.H and Statzner, B. (2006). Development in aquatic insect biomonitoring: A comparative analysis of recent approaches. Annual Review of Entomology 51: 495-523.

Bornette, G and Puijalon, S. (2011). Response of aquatic plants to abiotic factors: a review. Aquatic Sciences 73 (1): 1-14.

Buss, D.F., Carlisle, D.M., Chon, T., Culp, J., Harding, J.S., Keizer-Vlek, H.E., Robinson, W.A., Strachan, S., Thirion, C and Hughes, R.M. (2015). Stream bio-monitoring using macroinvertebrates around the globe: a comparison of large-scale programs. Environmental Monitoring and Assessment 187: 1-21.

Cairns, J., Buikema, A.L., Cherry, D.S., Herricks, E.E., van der Schalie, W.H., Matthews, R., Niederlehner, B.R and Rodgers, J.H. (1982). Biological Monitoring. Pergamon Press, London.

Chen, X., Zhoua, W., Pickett, S.T.A., Li, W., Han, L and Ren, Y. (2016). Diatoms are better indicators of urban stream conditions: A case study in Beijing, China 2016. Ecological Indicators 60: $265-274$.

Chutter, F.M. (1998). Research on the Rapid Biological Assessment of Water Quality Impacts in Streams and Rivers. Water Research Commission Report No 422/1/98 Water Research Commission, Pretoria.

Clarke, R.T and Hering, D. (2006). Errors and uncertainty in bioassessment methods-major results and conclusions from the STAR project and their application using STARBUGS. Hydrobiologia 566: 433-439.

Clews, E and Ormerod, S.J. (2009). Improving bio-diagnostic monitoring using simple combinations of biotic indices. River Research and Applications 25(3): 348 - 361.

Dalu, T and Froneman, P.W. (2016). Diatom-based water quality monitoring in southern Africa: challenges and future prospects. Water SA 42(4): 551-559.

De La Rey, P.A., Roux, H., van Rensburg, L and Vosloo, A. (2008). On the use of diatom-based biological monitoring Part 2: A comparison of the response of SASS 5 and diatom indices to water quality and habitat variation. Water $S A$ 34: 61-70.

De La Rey, P.A., Taylor, J.C., Laas, A., Van Rensburg, L and Vosloo, A. (2004). Determining the possible application value of diatoms as indicators of general water quality: A comparison with SASS 5. Water SA 30: 325-332.

De Pauw, N., Gabriels, W and Goethals, P. (2006). River monitoring and assessment methods based on macroinvertebrates. In: Biological monitoring of rivers; Application and perspectives, pp. 113-134 (Ziglio, G., Siligardi, M and Flaim, G. eds.). John Wiley \& Sons, UK.

Debenest, T., Silvestrea, J and Pinelli, E. (2013). Diatoms in ecotoxicology. In: Encyclopedia of Aquatic Ecotoxicology, pp. 295-304 (Férard, J.F., Blaise, C., eds.), Springer, Netherlands.

Dedieu, N., Clavier, S., Vigouroux, R., Cerdan, P and Céréghino, R., (2016). A multi-metric macroinvertebrate index for the implementation of the European water framework directive in French Guiana, East Amazonia. River Research \& Application 32: 501-515.

Dickens, C.W.S and Graham, P.M. (2002). The South African Scoring System (SASS) version 5 rapid bioassessment methods for rivers. African Journal of Aquatic Science 27: 1-10.

EEPA (Ethiopian Environmental Protection Authority) (2005). Assessment report on the status of Little Akaki rivers waters pollution. Addis Ababa, Ethiopia: Ethiopian Environmental Protection Authority.

EEPA (Ethiopian Environmental Protection Authority) (2010). Environmental management program of the plan for accelerated sustainable development to eradicate poverty 20112015. Addis Ababa, Ethiopia: Ethiopian Environmental Protection Authority. 
Environmental Laboratory (1987). Corps of Engineers wetland delineation manual. Y-87-I. U.S. Army Engineer Waterways Experiment Station, Vicksburg.

Elias, J.D., Ijumba, J.N and Mamboya, F.A. (2014). Effectiveness and compatibility of non-tropical bio-monitoring indices for assessing pollution in tropical rivers - A review. International Journal of Ecosystems 4: 128-134.

Everaert, G., Nguyen, H.H., Gabriels, W., Hoang T.H and Goethals, P.L.M. (2014). A multimetric macroinvertebrate index for assessing the water quality of the Cau river basin in Vietnam. Limnologica 45: 16-23.

EWNHS (Ethiopian Wildlife and Natural History Society and Wetlands International) (2018). A First Directory of Ethiopian Wetlands: Descriptions, Ecosystem Services, Causes of Degradation and Recommendations for Restoration and Sustainability. EWNHS and Wetlands International, $562 \mathrm{pp}$.

Fasikaw Atanaw, Mamaru Ayalew, Muluken Alemu, Essayas Kaba, Solomon Seyoum, Seifu Tilahun and Steenhuis, T.S. (2018). Budgeting suspended sediment fluxes in tropical monsoonal watersheds with limited data: the Lake Tana basin. Journal of Hydrology and Hydromechanics 66(1): 65-78.

Fennessy, S., Ibanez, C., Munne, A., Caiola, N., Kirchner, N and Sola, C. (2015). Biological Indices based on macrophytes: An overview of methods used in Catalonia and the USA to determine the status of rivers and wetlands. In: Experiences from Surface Water Quality Monitoring: The EU Water Framework Directive Implementation in the Catalan River Basin District, pp. 130-145 (Munne, A. et al., eds.), Springer International Publishing, Switzerland.

Ferreira, M.T., Rodriguez-Gonzalez, P.M., Aguiar, F.C and Albuquerque, A. (2005). Assessing biotic integrity in Iberian rivers: development of a multimetric plant index. Ecological Indicators 5: 137-149.

Friberg, N., Bonada, N., Bradley, D.C., Dunbar, M.J., Edwards, F.K., Grey, J., Hayes, R.B., Alan, G. Hildrew, A.G., Lamouroux, N., Trimmer, M and Woodward, G. (2011). Biomonitoring of Human Impacts in Freshwater Ecosystems: The Good, the Bad and the Ugly. Advances in Ecological Research 44: 1-68.

Gabriels, W., Lock, K., De Pauw, N and Goethals, P.L.M. (2010). Multi-metric macroinvertebrate index flanders (MMIF) for biological assessment of rivers and lakes in Flanders (Belgium). Limnologica 40(3): 199-207.

Gallardo, B., Clavero, M., Sanchez, M.I and Vila, M. (2016). Global ecological impacts of invasive species in aquatic ecosystems. Global Change Biology 22: 151-163.

Gernes, M.C and Helgen, J.C. (1999). Indexes of biotic integrity (IBI) for wetlands: vegetation and invertebrate IBI's. Final Report to U.S. Environmental Protection Agency. Minnesota Pollution Control Agency, Environmental Outcomes Division, St. Paul, MN.

Gernes, M.C and Helgen, J.C. (2002). Indexes of biological integrity (IBI) for large depressional wetlands in Minnesota. Final Report to U.S. Environmental Protection Agency. Minnesota Pollution Control Agency, Environmental Outcomes Division, St. Paul, MN.

Getachew Beneberu (2013). The family Chironomidae (Insecta: Diptera) as indicators of environmental stress, and macro-invertebrate based multimetric index development in some selected rivers in Ethiopia. PhD Thesis, Addis Ababa University, Ethiopia, 164 pp.

Getachew Beneberu and Seyoum Mengistou (2014). Head capsule deformities in Chironomus spp. (Diptera: Chironomidae) as indicator of environmental stress in Sebeta river, Ethiopia. African Journal of Ecology 3(3): 268-277.

Getachew Beneberu, Seyoum Mengistou, Eggermont, H and Verschuren, D. (2014). Chironomid distribution along a pollution gradient in Ethiopian rivers, and their potential for biological water quality monitoring. African Journal of Aquatic Science 39: 45-56.

Girma Tilahun and Tigist Ashagre (2012). Heavy metals accumulation by aquatic macrophytes from Lake Hawassa, Ethiopia: Phytoremediation for water quality improvement. In: Proceedings of the Second National Workshop on Challenges and Opportunities of Water Resources 
Management in Tana Basin, pp. 177-183 (Berihun Tefera, Workiye Worie and Melaku Wale. eds.). Blue Nile Water Institute - Bahir Dar University, Bahir Dar, Ethiopia.

Graichen, K. (2011). Lake water management in three Ethiopian Rift Valley watersheds. In: Colby Environmental Policy Group. 2011, pp. 97-128 (Cheever et al., eds.). Environmental Policy Review 2011: Key Issues in Ethiopia 2011. Waterville, Maine: Colby College Environmental Studies Program.

Gurmessa Tessema and Agumassie Tesfahun (2018). Assessment of benthic macroinvertebrate communities in relation to water quality in Teltele stream, Ambo West Showa, Ethiopia. Journal of Environmental Management and Public Safety 7(3): 043-052.

Habiba Gashaw and Seyoum Mengistou (2012). Ecological Assessment of Lake Hora, Ethiopia, Using Benthic and Weed-bed Fauna. Momona Ethiopian Journal of Science 4(2): 3-15.

Harrison, A.D and Hynes. H.B.N. (1988). Benthic fauna of Ethiopian mountain streams and rivers. Archiv fur Hydrobiologie Supplement 81: 1-36.

Hayal Desta and Seyoum Mengistou (2009). Water quality parameters and macroinvertebrates index of biotic integrity of the Jimma wetlands, Southwestern Ethiopia. Journal of Wetlands Ecology 3: 79-99.

Kaaya, L.T., Day, J.A and Dallas, H.F. (2015). Tanzania river scoring system (TARISS): A macroinvertebrate-based biotic index for rapid bioassessment of rivers. African Journal of Aquatic Science 40: 109-117.

Kaitho, R.J., Umunna, N.N., Nsahlai, I.V., Tamminga, S., VanBruchem, J., Hanson, J and Vande Wouw, M. (1996). Palatability of multipurpose tree species: effect of species and length of study on intake and relative palatability by sheep. Agroforestry Systems 33: 249-261.

Karr, J.R. (1981). Assessment of biotic integrity using fish communities. Fisheries 6(6): 21-27.

Karr, J.R and Chu, E.W. (1998). Restoring Life in Running Waters: Better Biological Monitoring. Island Press, Washington, D.C.

Karr, J.R and Chu, E.W. (2000). Sustaining living rivers. Hydrobiologia 422: 1-14.

Kennedy, M.P., Lang P., Grimaldo, J.T., Martins, S.V., Bruce, A., Lowe, S., Dallas, H., Tom, A., Davidson T.A., Sichingabula, H., Briggs, J and Murphy, K.J. (2016). The Zambian macrophyte trophic ranking scheme, ZMTR: A new biomonitoring protocol to assess the trophic status of tropical southern African rivers. Aquatic Botany 131: 15-27.

Kerans, B.L and Karr, J.R. (1994). A benthic index of biotic integrity (B-IBI) for rivers of the Tennessee Valley. Ecological Applications 4: 768-785.

Kitner, M and Poulièková, A. (2003). Littoral diatoms as indicators for the eutrophication of shallow lakes. Hydrobiologia 506/509: 519-524.

Kleynhans, C.J. (1999). The development of a fish index to assess the biological integrity of rapid bioassessment method for rivers. Water SA 25: 265-278.

Kloos, $\mathrm{H}$ and Worku Legesse (eds) (2010). Water resources management in Ethiopia: implications for the Nile Basin. Amherst, NY, Cambria Press.

Kolkwitz, R and Marsson, M. (1909). Okologie der tierischen Saprobien. Beitragazur Lehre von des biologischen Gewasserbeurteilung. Internationale Revue der gesamten Hydrobiologie und Hydrographie 2: 126-152.

Lang, P., Taylor, J.C., Bertolli, L., Lowe, S., Dallas, H., Kennedy, M.P., Gibbins, C., Sichingabula, H., Saili, K., Day, J., Willems, F, Briggs, J.A and Murphy, K.J. (2012). Proposed procedure for the sampling, preparation and analysis of benthic diatoms from Zambian rivers: a bioassessment and decision support tool applicable to freshwater ecoregions in tropical southern Africa. Southern African River Assessment Scheme (SAFRASS), Cape Town.

Leelahakriengkrai, P and Peerapornpisal, P. (2010). Diversity of benthic diatoms and water quality of the Ping river, Northern Thailand. Environment Asia 3(1): 82-94.

Levy, S. (2017). Paleoecology-looking to the past to inform the future. BioScience 67: 791-798.

Lobo, E.A., Callegaro, V.L., Hermany, G., Bes, D., Wetzel, C.E and Oliveira, M.A. (2004). Use of epilithic diatoms as bioindicator from lotic systems in southern Brazil, with special emphasis on eutrophication. Acta Limnologica Brasiliensis 16: 25-40. 
Lowe, S., Dallas, H., Kennedy, M.P., Taylor, J.C., Gibbins, C and Lang, P. (2013). The SAFRASS biomonitoring scheme, general aspects, macrophytes (ZMTR) and benthic macroinvertebrates (ZISS) protocols. SAFRASS Deliverable Report to the African, Caribbean and Pacific Group of States (ACP Group), Science and Technology Program, University of Glasgow, Glasgow.

Mack, J.J. (2001). Vegetation indices of biotic integrity (VIBI) for wetlands: Volume 1 Ecoregional, hydrogeomorphic, and plant community comparison with preliminary wetland aquatic life use designations. Final Report to U.S. Environmental Protection Agency. Ohio Environmental Protection Agency, Columbus, $\mathrm{OH}$.

Mangadze, T., Dalu, T and Froneman, P.W. (2019). Biological monitoring in southern Africa: A review of the current status, challenges and future prospects. Science of the Total Environment 648: $1492-1499$.

Masese, F.O., Omukoto, J.O and Nyakeya, K. (2013). Biomonitoring as a prerequisite for sustainable water resources: a review of current status, opportunities and challenges to scaling up in East Africa. Ecohydrology and Hydrobiology 13: 173-191.

Matthews, J.W., Spyreas, G and Endress, A.G. (2009). Trajectories of vegetation-based indicators used to assess wetland restoration progress. Ecological Applications 19: 2093-2107.

Mekedes Hone (2016). Assessing impact of tannery effluent along Blue Nile river using Chironomid larvae, Ethiopia. MSc Thesis, Bahir Dar University, Ethiopia. 64 pp.

Melaku Getachew, Argaw Ambelu, Seid Tiku, Worku Legesse, Aynalem Adugna and Kloos, H. (2012). Ecological assessment of Cheffa Wetland in the Borkena Valley, northeast Ethiopia: Macroinvertebrate and bird communities. Ecological Indicators 15: 63-71.

Mesfin Gebrehiwot, Aymere Awoke, Abebe Beyene, Demeke Kifle and Triest, L. (2017). Macroinvertebrate community structure and feeding interactions along a pollution gradient in Gilgel Gibe watershed, Ethiopia: Implications for biomonitoring. Limnologica 62: 68-76.

Miller, S.J., Wardrop, D.H., Mahaney, W.M and Brooks, R.P. (2006). A plant-based index of biological integrity (IBI) for headwater wetlands in central Pennsylvania. Ecological Indicators 6: $290-312$.

Moog, O., Schmutz, S and Schwarzinger, I. (2018). Biomonitoring and bioassessment. In: Riverine Ecosystem Management (Schmutz, S and Sendzimir, J., eds.). Aquatic Ecology Series 8, https://doi.org/10.1007/978-3-319-73250-3_19.

Muralidharan, M., Selvakumar, C., Sundar, S and Raja, M. (2010). Macroinvertebrates as potential indicators of environmental quality. Indian Journal of Biotechnology 1(Special Issue): 23-28.

Ndiritu, G.G., Gichuki, N.N and Triest, L. (2006). Distribution of epilithic diatoms in response to environmental conditions in an urban tropical stream, Central Kenya. Biodiversity Conservation 15: 3267-3293.

Ndiritu, G.G., Gichuki, N.N., Kaur, P and Triest, L. (2003). Characterization of environmental gradients using physico-chemical measurements and diatom densities in Nairobi river, Kenya. Aquatic Ecosystem Health and Management 6: 343-354.

Nel, J.L., Driver, A., Strydom, W., Maherry, A., Petersen, C., Hill, L., Roux, D.J., Nienabe, S., Van Deventer, H., Swartz, E.R and Smith-Adao L. (2011). Atlas of freshwater ecosystem priority areas in South Africa, Maps to Support Sustainable Development of Water Resources. WRC Report NoTT 500/11.Water Resources Commission, Pretoria.

Nguyen, H.H., Everaert, G., Gabriels, W., Hoang, T.H and Goethals, P. (2014). A multimetric macroinvertebrate index for assessing the water quality of the Cau River Basin in Vietnam. Limnologica 45: 16-23.

Nichols, S., Weber, S and Shaw, B. (2000). A proposed aquatic plant community index for Wisconsin Lakes. Environmental Management 26: 491-502.

Ochieng, H., Okot-Okumu, J and Odong, R. (2019). Taxonomic challenges associated with identification guides of benthic macroinvertebrates for biomonitoring freshwater bodies in East Africa: A review. African Journal of Aquatic Science, DOI: 10.2989/16085914.2019.1612319. 
Oliveira, V., Martins, R and Alves, R. (2010). Evaluation of water quality of an urban stream in southeastern Brazil using Chironomidae Larvae (Insecta: Diptera). Neotropical Entomology 39(6): 873-878, http://dx.doi.org/10.1590/S1519-566X2010000600004.

Palmer, R.W and Taylor, E.D. (2004). The Namibian scoring system (NASS) version 2 rapid bioassessment method for rivers. African Journal of Aquatic Science 29: 229-234

Pandey, L.K and Bergey, E.A. (2016). Exploring the status of motility, lipid bodies, deformities and size reduction in periphytic diatom community from chronically metal $(\mathrm{Cu}, \mathrm{Zn})$ polluted waterbodies as a biomonitoring tool. Science of the Total Environment 550: 372-381.

Pandey, L.K., Lavoie, I., Morin, S., Park, J., Jie, L., Choi, S., Lee, H and Han, H. (2018). River water quality assessment based on a multi-descriptor approach including chemistry, diatom assemblage structure, and non-taxonomical diatom metrics. Ecological Indicators 84: 140-151.

Plafkin, J.L., Barbour, M.T., Porter, K.D., Gross, S.K and Hughes, R.M. (1989). Rapid bioassessment protocols for use in streams and rivers: Benthic macroinvertebrates and fish. U.S. Environmental Protection Agency, Washington, D.C., 674 pp.

Potapova, M and Charles, D.F. (2003). Distribution of benthic diatoms in U.S. Rivers in relation to conductivity and ionic composition. Freshwater Biology 48: 1311-1328.

Resh, V.H. (2007). Multinational, freshwater biomonitoring programs in the developing world: Lessons learned from African and Southeast Asian river surveys. Environmental Management 39: $737-748$.

Resh, V.H. (2008). Which group is best? Attributes of different biological assemblages used in freshwater biomonitoring programs. Environmental Monitoring and Assessment 138: 131-138.

Rühland, K., Alisha Priesnitz, A., John, P and Smol, J.P. (2003). Paleolimnological Evidence from Diatoms for Recent Environmental Changes in 50 Lakes across Canadian Arctic Treeline. Arctic, Antarctic, and Alpine Research 35(1): 110-123.

Schierup, H.H and Larsen, V.J. (1981). Macrophyte cycling of zinc, copper, lead and cadmium in the littoral zone of a polluted and a non-polluted lake. I. Availability: uptake and translocation of heavy metals in Phragmites australis (Cav.) Trin. Aquatic Botany 11: 197-210.

Seid Tiku, Boets, P., De Meester, L and Goethals, P.L.M. (2013). Development of a multimetric index based on benthic macroinvertebrates for the assessment of natural wetlands in Southwest Ethiopia. Ecological Indicators 29: 510-521.

Selamawit Negassa, Boets, P., Goethals, P.L.M and Seid Tiku (2018a). Does the protection status of wetlands safeguard diversity of macroinvertebrates and birds in southwestern Ethiopia? Biological Conservation 226: 63-71.

Selamawit Negassa, Boets, P., Seid Tiku, Ho, L.T and Goethals, P.L.M. (2018b). Using macroinvertebrates and birds to assess the environmental status of wetlands across different climatic zones in southwestern Ethiopia. Wetlands, https://doi.org/10.1007/s13157-018-1008-7.

Seleshi Bekele Awulachew, Smakhtin, V., Molden, D and Peden, D. (eds) (2012). The Nile River Basin: Water, Agriculture, Governance and Livelihoods, $1^{\text {st }}$ edition. International Water Management Institute, Routledge, 2 Park Square, Milton Park, Abingdon, 346 pp.

Seo, A., Lee, K., Kim, B and Choung, Y. (2014). Classifying plant species indicators of eutrophication in Korean lakes. Paddy Water Environment 12: 29-40.

Seyoum Mengistou (2006). Status and challenges of aquatic invertebrate research in Ethiopia: A review. Ethiopian Journal of Biological Sciences 5(1): 75-115.

Simkhada, B., Jüttner, I and Chimonides, P.J. (2006). Diatoms in lowland ponds of KoshiTappu, Eastern Nepal-relationships with chemical and habitat characteristics. International Review of Hydrobiology 91: 574-593.

Sisay Misganaw (2018). Macroinvertebrates as indicators of the water quality of river Shinta, Gondar, Ethiopia. Sustainable Water Resources Management; https://doi.org/10.1007/s40899018-0297-6.

Silva, D.R.O., Herlihy, A.T., Hughes, R.M and Callisto, M. (2017). An improved macroinvertebrate multimetric index for the assessment of wadable streams in the neotropical savanna. Ecological Indicators 81: 514-525. 
Solomon Akalu (2017). Macroinvertebrate-based bioassessment of rivers in Addis Ababa, Ethiopia. African Journal of Ecology, DOI: 10.1111/aje.12444.

Solomon Akalu, Seyoum Mengistou, and Seyoum Leta (2011). Assessing human impacts on the Greater Akaki river, Ethiopia using macroinvertebrates. SINET: Ethiopian Journal of Science 34: 89-98.

Stevenson, J. (2014). Ecological assessments with algae: a review and synthesis. Journal of Phycology 50: 437-461.

Stevenson, R.J., Pan, Y and Vandam, H. (2010). Assessing environmental conditions in rivers and streams with diatoms. In: The Diatoms: Applications for the Environmental and Earth Sciences (Smol, J.P., Stoermer, E.F. eds.), $2^{\text {nd }}$ edition. Cambridge University Press.

Stoermer, E.F and Smol, J.P. (1999). The diatoms: Applications for the environmental and earth sciences. Cambridge, New York, Melbourne: Cambridge University Press.

Tadesse Fetahi (2019). Eutrophication of Ethiopian water bodies: a serious threat to water quality, biodiversity and public health. African Journal of Aquatic Science 44(4): 303-312.

Taffere Addis (2008). Comparative study of macroinvertebrates and diatoms as bioindicators of river water quality in Addis Ababa, MSc Thesis, Addis Ababa University, Ethiopia, 87 pp.

Taylor, J.C., Harding, W.R and Archibald, C.G.M. (2007a). An illustrated guide to some common diatom species from South Africa. WRC Report TT 282/07. Pretoria: Water Research Commission.

Taylor, J.C., Prygiel, J., Vosloo, A., De La Rey, P.A and Van Rensburg, L. (2007b). Can diatombased pollution indices be used for biomonitoring in South Africa? A case study of the Crocodile West and Marico water management area. Hydrobiologia 592: 455-464.

Temesgen Alemneh, Argaw Ambelu, Bahrndorff, S., Seid Tiku, Pertoldi, C and Zaitchik, B.F. (2017). Modeling the impact of highland settlements on ecological disturbance of streams in Choke Mountain Catchment: Macroinvertebrate assemblages and water quality. Ecological Indicators 73: 452-459.

Temesgen Alemneh, Zaitchik, B.F., Bahrndorff, S., Argaw Ambelu, Seid Tiku and Pertoldi, C. (2019). A macroinvertebrate multi-metric index for Ethiopian highland streams. Hydrobiologia, https://doi.org/10.1007/s10750-019-04042-x.

Tenalem Ayenew (2007). Water management problems in the Ethiopian rift: Challenges for development. Journal of African Earth Sciences. 48(2-3): 222-236.

Tenalem Ayenew and Dagnachew Legesse (2007). The changing face of the Ethiopian rift lakes and their environs: call of the time. Lakes and Reservoirs: Research and Management 12: 149-165.

Tesfaye Berhe, Harrison, A.D and Hynes, H.B.N. (1989). The degradation of a stream crossing the City of Addis Ababa, Ethiopia. Tropical Freshwater Biology 2: 112-120.

Tesfaye Berhe (1988). The Degradation of the Abo-Kebena River in Addis Ababa, Ethiopia. MSc Thesis, Addis Ababa University, Ethiopia, $110 \mathrm{pp}$.

Thorne, S.R and Williams, W.P. (1997). The response of benthic macroinvertebrates to pollution in developing countries: a multimetric system of bioassessment. Freshwater Biology 37: 671-686.

Triest, L., Lung'ayia, H., Ndiritu, G and Abebe Beyene (2012). Epilithic diatoms as indicators in tropical African rivers (Lake Victoria catchment). Hydrobiologia 695: 343-360.

Tudorancea, C and Taylor, W.D. (eds) (2002). Ethiopian Rift Valley lakes. Backhuys Publishers, Leiden, the Netherlands.

USEPA (1987). Surface water monitoring: A framework for change. U.S. Environmental Protection Agency, Office of Water, Office of Policy Planning and Evaluation, Washington, D.C.

USEPA (2002). Methods for evaluating wetland condition: Biological assessment methods for birds. Office of Water, U.S. Environmental Protection Agency, Washington, D.C.

USEPA (2013). Biological assessment program review: Assessing level of technical rigor to support water quality management. Office of Science and Technology, Washington, D.C.

Vannote, R.L., Minshall, G.W., Cummins, K.W., Sedell, J.R and Cushing, C.E. (1980). The river continuum concept. Canadian Journal of Fisheries and Aquatic Sciences 37:130-137. 
Wagenhoff, A., Shearer, K and Clapcott, J. (2016). A review of benthic macroinvertebrate metrics for assessing stream ecosystem health. Prepared for Environment Southland. Cawthron Report No. 2852,58 pp.

Wassie Anteneh, Abebe Getahun and Eshete Dejen (2010). Assessment of downstream dispersal of juveniles of the migratory riverine spawning Labeobarbus spp. of Lake Tana. In: Management of Shallow Water Bodies for Improved Productivity and Peoples' Livelihoods in Ethiopia, pp. 161-172 (Seyoum Mengistou and Brook Lemma, eds.). Addis Ababa, Ethiopia: Addis Ababa University Press.

Wolska, L.W., Sagajdakow, A., Kuczyńsk, A and Namieśnik, J. (2007). Application of ecotoxicological studies in integrated environmental monitoring: possibilities and problems. Trends in Analytical Chemistry 26: 332-344.

Worku Legesse (2000). Physicochemical and biological assessment of the Kebena river, Addis Ababa, Ethiopia. PhD Thesis, National University of Ireland, Cork.

Yetneberk Kassaye, Skipperud, L., Einset, J and Salbu, B. (2016.) Aquatic macrophytes in Ethiopian Rift Valley lakes; Their trace elements concentration and use as pollution indicator. Aquatic Botany 134: 18-25.

Yezbie Kassa (2016). Macrophyte ecology, nutrient dynamics and water quality of the littoral zone, and Yitamot Wetland, Lake Tana, Ethiopia. PhD dissertation, Addis Ababa University, Ethiopia, $215 \mathrm{pp}$.

Yu, S., Chen, W., He, X., Liu, Z., Song, H., Ye, Y and Jia, L. (2014). A comparative study on nitrogen and phosphorus concentration characteristics of twelve riparian zone species from upstream of Hunhe River. CLEAN -Soil, Air and Water Pollution 42: 408-414.

Zinabu G/Mariam, Kebede-Westhead, E and Zerihun Desta (2002). Long-term changes in chemical features of waters of seven Ethiopian rift-valley lakes. Hydrobiologia 477: 81-91.

Zinabu G/Mariam (1998). Human interactions and water quality in the Horn of Africa. Available at http://www.aaas.org/international/africa/ewmi/zinabu.htm, (Accessed November 30, 2011).

Zinabu G/Mariam and Elias Dadebo (1989). Water resources and fisheries management in the Ethiopian Rift Valley lakes. SINET: Ethiopian Journal of Science 12: 95-109. 